\title{
MacArthur Fellows, 1981-2018: Gender, Race and Educational Attainment
}

\author{
Amadu Jacky Kaba \\ Department of Sociology, Anthropology and Social Work, Seton Hall University, South Orange, New Jersey, USA \\ Email:kabaamad@shu.edu
}

How to cite this paper: Kaba, A. J. (2020). MacArthur Fellows, 1981-2018: Gender, Race and Educational Attainment. Sociology Mind, 10, 86-126.

https://doi.org/10.4236/sm.2020.102008

Received: March 6, 2020

Accepted: April 27, 2020

Published: April 30, 2020

Copyright $\odot 2020$ by author(s) and Scientific Research Publishing Inc. This work is licensed under the Creative Commons Attribution International License (CC BY 4.0).

http://creativecommons.org/licenses/by/4.0/ (c) (i) Open Access

\begin{abstract}
This study examines the backgrounds of the winners of the MacArthur Fellowship grants from 1981 to 2018, from the conceptual framework of the term "genius". The study finds that of the 1014 Fellows, Whites account for over eight out of every ten; minorities account for almost 20\%; men account for almost 63\%; White men account for $51.3 \%$; Blacks account for $12.5 \%$; Asians account for 5.9\%; and Native Americans account for 1.2 percent. Of 965 terminal or highest degrees earned by 928 Fellows, 540 (56\%) are doctorates, with the Ph.D. accounting for 514 (53.3\%). White men earned the majority of all degrees (50.8\%). Harvard University awarded the highest number of degrees, 119: Yale University, 61; University of California, Berkeley, 51; Columbia University, 44; and Princeton University, 41. All eight Ivy league institutions awarded 306 (31.7\%) degrees to 300 (32.3\%) Fellows. The 2020 U.S. News and World Report Top 25 institutions combined awarded 522 degrees $(54.1 \%)$ to 514 Fellows (55.5\%). There is a link among earned doctoral degrees, foreign-born males, and the overall gender gap in the study.
\end{abstract}

\section{Keywords}

MacArthur, Genius, Terminal Degrees, Gender, Race, Ph.D.

\section{Introduction}

One of the most important contributing factors for advanced or developed societies or countries to have the status or prestige they enjoy today is the productivity (scientific and cultural) of their colleges, universities, research institutes and centers. One can safely claim that a society's progress or advancement is correlated with the quality and quantity of its higher education institutions. Research by Kaba (2012a) of the 2009 Times Higher Education top 200 ranked universities in the world shows that 54 (27\%) were located in the United States; 
$29(15 \%)$ in the United Kingdom; $11(5.5 \%)$ each in Canada, Japan, and the Netherlands; 10 (5\%) in Germany; and 9 (4.5\%) in Australia (p. 9). These are also among the nations with the largest gross domestic product (GDP) and GDP per capita in the World. Their ranked universities tend to have the largest endowments in the world. For example, Kaba's (2012a) study found that the combined endowment of all eight Ivy League universities (Brown University, Cornell University, Dartmouth College, Columbia University, Harvard University, Princeton University, University of Pennsylvania, and Yale University) ranked in the 2009 Times Higher Education top 200 universities in 2007, was $\$ 98.7$ billion (p. 28). To put this in context of how substantial this total endowment of these universities is, as of December 17, 2018, the World Factbook lists 230 nations and entities based on their 2017 gross domestic product. The $\$ 98.7$ billion combined endowment of all eight Ivy League institutions in 2007 would rank number 86, below Croatia ( $\$ 102.1$ billion), ranked number 85 , and above Côte d'Ivoire ( $\$ 97.1$ billion), ranked number eighty-six.

Students or their families and governments of societies where those higher education institutions are located are primarily responsible for funding higher education. In addition, philanthropic organizations such as foundations make significant contributions in supporting the education and research of those who are enrolled or work at colleges and universities. Some of the largest or wealthiest foundations are international in their giving, while others are more nationally or domestically focused. The majority of foundations provide grants, meaning that a person, group or entity must submit an application, wait for a decision, and if the decision is yes, a report is usually required to provide a summary of the project. Some foundations, on the other hand, can provide no strings attached support to individuals or organizations. In such an instance, the recipient of the award, grant or fellowship is not aware whether their name is submitted for such an award. Internationally, the Nobel Memorial Prize is an example of an award that comes with a substantial amount of money and gold medal, where the recipient does not submit an application (Zuckerman, 1992; Wallerstein, 2002). Nationally, in the United States, the MacArthur Fellowship Program is an example of a no strings attached money of over $\$ 600,000$ awarded annually to dozens of talented individuals from all walks of life during a five-year period to be used whichever way they wish to help them in their academic research or artistic creations.

\section{The MacArthur Fellowship Program}

The MacArthur Fellows Program was established in 1981 by the MacArthur Foundation. According to the MacArthur Foundation: "The MacArthur Fellowship is a 'no strings attached' award in support of people, not projects. Each fellowship comes with a stipend of $\$ 625,000$ to the recipient, paid out in equal quarterly installments over five years." The Foundation also adds that the Fellows Program intends: "to encourage people of outstanding talent to pursue 
their own creative, intellectual, and professional inclinations ... Recipients may be writers, scientists, artists, social scientists, humanists, teachers, entrepreneurs, or those in other fields, with or without institutional affiliations. They may use their fellowship to advance their expertise, engage in bold new work, or, if they wish, to change fields or alter the direction of their careers" (About MacArthur Fellows Program, 2019; also see Coutu, 2007; "MacArthur Fellows Program: Summary of 2012-2013 Review," 2013; Wallerstein, 2002; Ward, 2001; Zuckerman, 1992: p. 218). There are two terms or words that the public, especially the media have used to identify the MacArthur Fellowship Program: "Genius" and "Creativity". The public almost always refers to the Fellows Program as the "Genius" award, while some, including the MacArthur Foundation itself refers to the word "creative" of "creativity" to discuss the Program.

There have been numerous published scholarly peer reviewed journal articles, books, public intellectual articles in periodicals, dissertations, and newspaper articles combined focusing on various aspects of the backgrounds of MacArthur Fellows. Most of these publications focus on the profiles or backgrounds of the fellows (Cox \& Daniel, 1984; Von Gunten, 2009; Moritz, 1998; Pais, 2011; Powell, 2008; Schimke, 2016). Others focus on the history and characteristics of the MacArthur Fellowship Program (Coutu, 2007; Ward 2001; Zuckerman, 1992). Some of these publications also focus on the impact of the Fellows Program on the Fellows' careers (Frank, 2014; Powell, 2008; Rocca, 2017; Schimke, 2016; Silka, 2014), while others tend to criticize various aspects of the Program, including the selection method (Benzon, 2018; Kinsley, 1981; Rocca, 2017: p. 85; Wooster, 2010). For example, according to Rocca (2017), the MacArthur Fellowship Program was "... created to correct for the perceived alienation of genius in American culture, [but] it tended to produce yet more alienation" (p. 85). From 1981 to 2018, a total of 1,014 individuals have been selected as MacArthur Fellows. It is noted that out of “... 2000 people nominated each year, between 20 and 25 ..." receive the Fellowship (Schimke, 2016: p. 38).

The MacArthur Foundation has also published a number of studies and reports on the MacArthur Fellowship Program, focusing on the backgrounds of the Fellows and the success of the Program (MacArthur Fellows: The First 25, 1981-2005; "MacArthur Fellows Program: Summary of 2012-2013 Review," 2013; "Review Affirms Impact and Inspiration," 2013). One such publication presents data on the undergraduate alma maters of the Fellows (Conrad, 2017). Another study focuses on the place of birth of the Fellows ("Fellows Location at Birth," 2018). Another study focuses on the U.S. state or country where a Fellow was located when they won the award ("Fellows Location at Award," 2018). This current study will build on the research findings or results of a number of these publications.

One important limitation of the various publications mentioned above on the MacArthur Fellowship Program is that none of them examined the gender and racial/ethnic breakdowns, and the terminal or highest academic degrees earned 
by all of the Fellows. A study containing such findings will make a significant contribution to the understanding of the types of people receiving these fellowships. This information is very important especially in a country as diverse as the United States.

This study examines the backgrounds of MacArthur Fellows for the almost four decades period from 1981 to 2018. The study begins by defining or conceptualizing the term "Genius". Next, the methodology section explains how the data for this study were collected and computed. For example, the concept of race or the racial categorization of people in the United States is significantly different than in other societies or nations. Next, the findings or results section of this study are presented. For example, the overall gender gap would have been a lot higher had it not been the selection of increasing numbers of women (now at $37 \%$ ) in the past decade. Finally, a discussion section is presented to make sense of the numerous interrelated findings or results. For example, there is a link among earned doctoral degrees, foreign-born males, and the overall gender gap in the study. This means that if the selection criteria for Fellows were limited to native-born United States citizens, then the gender gap could have been smaller.

\section{Defining the Term Genius}

The public tends to refer to MacArthur Fellows as geniuses, while the MacArthur Fellowship Program utilizes the word creative or creativity to refer to them or describe them. It has been widely noted that the MacArthur Fellowship Program has never officially used the term genius to refer to Fellows. According to von Gunten (2009), "The popular press has generally characterized these as 'genius' awards" (p. 5). As Wooster (2014) notes: “The first article to refer to the fellowships as 'genius grants' was written by Diane Shah in Newsweek in 1979-two years before the fellowships program was started." According to the Managing Editor of the MacArthur Fellowship Program, Dr. Cecilia Conrad (2013): “The foundation does not use the name 'genius' grant; the news media coined that nickname in 1981, when we announced our first class of fellows, and it stuck." Instead, the MacArthur Fellowship Program has utilized the term creative or creativity. According to Sternberg (2006), creativity entails the convergence of six different but interrelated resources: "intellectual abilities, knowledge, styles of thinking, personality, motivation, and environment" (p. 88). It is therefore useful to present definitions or explanations of the term genius. A primary reason for this is that the definition of genius by one person may be different from another person's understanding of the term. As Goldberg (2017) points out, “... it's hard to tell who among the living truly is a genius” (p. C5). A careful examination of numerous scholarly journal articles, public intellectual journal articles, books, etc. shows various interrelated definitions of the term genius, but a debate exists as to what type of person should be considered a genius, or what the characteristics of a genius must be. Moreover, many of the defini- 
tions of the term genius include the word creativity.

Epstein (2013) points out that: "The definitions for genius may be greater than the actual number of true geniuses" (p.38; also see Garber, 2002: p. 65). According to Kalb (2017): "Genius is too elusive, too subjective, too wedded to the verdict of history to be easily identified. And it requires the ultimate expression of too many traits to be simplified into the highest point on one human scale" (p. 42). Brinkman (2010) notes that, "The concept of genius is both revered and reviled in modern society" (p. 124). Garber (2002) points out that: "The word "genius" derives from the same root as "gene" and "genetic," and meant originally, in Latin, a tutelary god or spirit given to every person at birth" (p. 67). Garber (2002) adds that the term genius, which is an eighteenth century word, “... continues to be, the Romantic hero, the loner, the eccentric, the apotheosis of the individual" (p. 65). Andrews (2018) defines a genius as one with "exceptional intellectual or creative power or other natural ability" (p. 27). Brinkman (2010) explains " $\ldots$ the components of creative genius, including talent, intelligence, memory, and the unconscious, ..." (p. 124; also see Benzon, 2018). Using the academic discipline or field of psychology to define genius using Intelligence Quotient (IQ) tests, Orner (2016) claims that the term describes “... a person who has an extraordinarily high level of intellectual power ... it is designated by exceptional creative ability and achievement" (also see Kalb, 2017: p. 42; Coutu, 2007: p. 122).

Epstein (2013) explains how rare geniuses are, and attempts to describe them by comparing them to learned individuals: " $\mathrm{A}$ man of learning is a man who has learned a great deal; a man of genius, one from whom we learn something which the genius has learned from nobody" (p. 38). Epstein (2013) adds that: A genius is not merely brilliant, skillful, masterly, sometimes dazzling; he is miraculous, in the sense that his presence cannot be predicted, explained, or accounted for (at least thus far) by natural laws or scientific study" (p. 38). Isaacson (2017) also compares a genius to a "supersmart" individual by pointing out that: "Smart people are a dime a dozen, and many of them don't amount to much. What matters is creativity, the ability to apply imagination to almost any situation" (p. 62).

Patchett (2017) discusses who a genius is through the question of what it would require: “... knowing the thing you are meant to do in life, and then doing it without regard for the time it will take?" (p. 64). This means that hard work, dedication and perseverance are important components of being a genius. As von Gunten (2009) notes, "Thomas A. Edison is famously remembered to have said, 'Genius is $10 \%$ inspiration and $90 \%$ perspiration'” (p. 5; also see Simonton, 2017: 126). According to Kalb (2017): "Natural gifts and a nurturing environment can still fall short of producing a genius, without motivation and tenacity propelling one forward. These personality traits, which pushed Darwin to spend two decades perfecting Origin of Species and Indian mathematician Srinivasa Ramanujan to produce thousands of formulas ..." (p. 47). Kalb (2017) cites a 
female MacArthur Fellow who notes that passion and perseverance combined, which she calls "grit" is the drive behind people's achievements. The idea of being a genius is not disguised within magic to make it seem that the important achievements of individuals happen spontaneously without hard work: “... there are differences when it comes to individual talent, but no matter how brilliant a person, fortitude and discipline are critical to success. 'When you really look at somebody who accomplishes something great,' ... 'it is not effortless"' (p. 47). Kalb (2017) points out that one can attempt to understand the term genius: “... by unraveling the complex and tangled qualities-intelligence, creativity, perseverance, and simple good fortune, to name a few-that entwine to create a person capable of changing the world" (p. 42).

One criticism of this concept of genius, which many tend to connect to those selected to become MacArthur Fellows, is that a higher percentage of individuals from certain groups or categories (sex/gender, race or ethnic origin), could be considered to be geniuses. For example, Kalb (2017) cites a scholar who caution's people on the use of the word genius because It can ".. be a societal judgment that elevates a chosen few while overlooking others-but to nurture imagination in everyone" (p. 43). Goldberg (2017) also notes that the first time editors of the National Geographic magazine "... gathered portraits to create a gallery of geniuses past ... the uniformity was obvious-and unsettling. In the sciences and arts, statecraft and literature, philosophy and industry, those hailed as geniuses were most often white men, of European origin" (p. C5).

The various definitions or explanations presented above as to who is a genius tend to show that it is someone who can either have formal or informal education. This person is passionate about a topic or multiple topics. He or she enjoys working for long hours on a task and is disciplined and persistent. He or she is so dedicated that they would persevere on a project even if it takes them decades to complete. To be a genius then is not just having mental skills, but also dedication and patience.

\section{Methodology, Data Availability and Limitations of This Study}

\subsection{Methodology}

This research project started in June 2017. The data were collected from June 2017 to October 2018. Its aim is to make a useful contribution to the body of knowledge that has been produced on the MacArthur Fellowship Program. The MacArthur Fellowship Program presents the photos of almost all of its Fellows. It also presents background information of all Fellows under their names and photos, including profession, year fellowship was awarded, employment affiliation, geographic location when fellowship was awarded, age at the time of award, and academic degrees (https://www.macfound.org/fellows/search/all). For Fellows without available photos on the MacArthur Fellowship Program's website, I searched their employment or personal websites or google image to find a photo 
of them.

The compilation of highly gifted individuals in a period of almost four decades is a very important development because these individuals are from all walks of life and are recognized by both the MacArthur Foundation and the general public as creativists and geniuses. For example, the Fellows are professionals of all kinds: anthropologists, archaeologists, architects, artists, attorneys, authors, biologists, cartoonists, chemists, choreographers, civil rights leaders, community organizers, composers, computer scientists, conservationists, economists, educators, engineers, farmers, filmmakers, geologists, historians, illustrators, inventors, journalists, linguists, mathematicians, medical doctors, musicians, novelists, painters, paleobotanists, philosophers, physicists, planetary scientists, playwrights, poets, political scientists, psychologists, screenwriters and producers, sculptors, sociologists, statisticians, translators, and writers (Compiled by author based on data from: https://www.macfound.org/fellows/search/all).

Most of the Fellows also work at great colleges and universities in the United States, including: Arizona State University, Boston University, Brown University, Bryn Mawr College, California Institute of Technology, Carnegie Mellon University, City University of New York, College of the Holy Cross, Columbia University, Drexel University, Harvard University, Indiana University, Johns Hopkins University, Massachusetts Institute of Technology, Missouri State University, Northwestern University, New York University, Princeton University, Rockefeller University, Rutgers University, New Jersey, Stanford University, Stony Brook University, the University of California, Berkeley, University of California, Los Angeles, University of California, San Diego, the University of Chicago, University of Colorado, University of Illinois at Urbana-Champaign, University of Massachusetts, Amherst, University of Maryland, College Park, University. of Michigan, University of New Hampshire, University of North Carolina, Chapel Hill, University of Tennessee, Knoxville, University of Texas, Austin, University of Pennsylvania, University of San Francisco, University of Southern California, University of Utah, University of Washington, University of Wisconsin, Milwaukee, Princeton University, State University of New York, Albany, Syracuse University, Vanderbilt University, Virginia Polytechnic Institute and State University, Wesleyan University, and Yale University.

However, while a significant body of research has examined various aspects of these Fellows' backgrounds, the public has not been provided with information showing the proportion of women and men, racial or ethnic backgrounds, or their highest or terminal degrees. This study aims to add these variables to the understanding of who these gifted individuals are.

The variables examined in this study include: sex/gender, race/ethnicity, earned terminal/highest academic degree, type of academic degree, alma mater, location of alma mater (U.S. state, region and country).

The sex/gender variable is based on a careful examination of the pictures of every Fellow and how they are described in the media or academic publications whether as he or she. There is one instance where the MacArthur Fellowship 
Program did not identify a Fellow as he or she, and a number of media reports identified the individual as transsexual (from male to female). I therefore included that Fellow in the female/women category in this study.

The race variable is based on the classifications of the various racial groups in the United States federal government (Gans, 2012; Kaba, 2015: pp. 120-121; "Standards for the Classification of Federal Data on Race and Ethnicity," 1995; Yancey 2003). For example, Kaba (2017a) cites the White House Office of Management and Budget as claiming that: "The term 'Black' in Directive No. 15 refers to a person having origins in any of the Black racial groups of Africa." Explaining who belongs to the White category: "In Directive No. 15, the 'White' category includes persons having origins in any of the original peoples of Europe, North Africa, or the Middle East" (p. 20). This means that a Fellow with a visible or significant Black African blood is categorized as Black. A Fellow from South Asian nations such as Bangladesh, India, Pakistan or Sri Lanka, or East or Southeast Asian nations such as China, Japan, North Korea, South Korea, Philippines, Thailand, or Vietnam is categorized as Asian. A Fellow with ancestry from Israel, Turkey, Iran, Central Asia or Arab is categorized as White. A Fellow with European ancestry is categorized as White. A Fellow with mixed Asian ancestry and any of the groups just categorized as White above is also categorized as White (Jilani, 2020). There is one male Fellow with a Mexican mother and a Chinese father and he is categorized as Chinese (Asian) in this study. The reason is that most native Mexicans have DNA traced back to Asia.

The educational attainment data focuses on a Fellow's earned highest or terminal college or higher education degree(s). If a Fellow has an earned bachelor's degree or higher, I only count the highest degree. If he or she has any number of master's degrees only, I counted them all. If he or she has an earned master's and a JD, I counted only the JD. If he or she has an earned master's degree and a doctorate degree (such as Ph.D. or Ed.D.), I counted only the doctorate degree; I combined or counted a doctorate and an MD (Doctor of Medicine), or a doctorate and a JD (Juris Doctor). If a Fellow has one or more bachelor's degrees only, I counted them all. If a Fellow has one or more Associate degrees only (from a community or two-year college), I counted them all. If a Fellow has an MD and an MPA, MHA, or MBA, I only counted the MD. If a Fellow has a JD and an L.L.M., I only counted the JD. The reason is that for the most part, one has to have a JD to qualify to get an L.L.M., but the vast majority of people with a JD do not seek an L.L.M. The types of academic degrees include B.A., B.S., M.A., M.S., Ph.D., and Ed.D. The MacArthur Fellowship Program tends to periodically update the information of its Fellows, including educational attainment data. However, in the instances where I did not find a Fellow with a college degree on the MacArthur Fellowship Program's website, I searched the Fellow's website and any relevant publications to determine whether he or she has an earned college degree. For example, it was through this method that I found out that the youngest female Macarthur Fellow, Lateefah Simon (who won the award at age 26 in 2003), earned a bachelor's degree in public policy from Mills College in 
California in 2017.

\subsection{Data Availability and Limitations of This Study}

The regional data are for both the four regions of the United States (Midwest, Northeast, South and West) and the regions of the world based on the United Nations' categorization (see appendices section). I carefully rechecked all of the data I compiled several times for accuracy. For example, I was able to confirm the claim by the MacArthur Fellowship Program that from 1981 to October 2018, 1014 Fellows had been selected, through entering and counting the data of every single Fellow.

I did not contact any Fellow for any missing information pertaining to that Fellow. Apart from compiling the data from the MacArthur Fellowship Program's website, I did not contact any official at the Program to request a particular information about a Fellow. As explained above, if information is missing for a particular Fellow, I either clearly state that fact or I attempted to search the web for such information. The reason is that If I were to contact one person for missing information, they either would not feel comfortable providing such data or I may need to do the same for every Fellow with missing data. As a result, this study could not be completed.

\section{Findings/Results and Analysis}

\subsection{Gender/Sex and Racial Categories of MacArthur Fellows, 1981-2018}

I have conducted numerous studies of prominent or gifted individuals in the past decade, and I have also examined studies conducted in the past several decades of such individuals. One finding that has remained constant in these studies is that regardless of race, ethnicity, or geographic location, males outnumber their female counterparts (Kaba, 2012b, 2013ab, 2015, 2016, 2017ab). This current study observes the continuation of that trend. For example, according to Table 1 , of the 1014 MacArthur Fellows selected from 1981 to 2018, 637 (62.8\%) are men and $377(37.2 \%)$ are women. Whites account for $815(80.4 \%)$ of all Fellows.

Table 1. Sex/Gender and Racial Breakdowns of MacArthur Fellows, 1981 to 2018 ( $\mathrm{N}=$ 1014).

\begin{tabular}{ccccccccc}
\hline Race & Men & $\begin{array}{c}\text { \% of } \\
\text { Men }\end{array}$ & $\begin{array}{c}\text { \% of } \\
\text { Total }\end{array}$ & Women & $\begin{array}{c}\text { \% of } \\
\text { Women }\end{array}$ & $\begin{array}{c}\text { \% of } \\
\text { Total }\end{array}$ & Total & $\begin{array}{c}\text { \% of } \\
\text { Total }\end{array}$ \\
\hline Asian & 40 & 6.3 & 3.94 & 20 & 5.3 & 1.98 & 60 & 5.9 \\
Black & 73 & 11.5 & 7.2 & 54 & 14.3 & 5.3 & 127 & 12.5 \\
Native American & 4 & 0.6 & 0.4 & 8 & 2.1 & 0.8 & 12 & 1.2 \\
White & 520 & 81.6 & 51.3 & 295 & 78.3 & 29.1 & 815 & 80.4 \\
Total & 637 & 100 & 62.8 & 377 & 100 & 37.2 & 1014 & 100 \\
\hline
\end{tabular}

Source: Compiled and computed based on data provided by the MacArthur Fellowship Program (June 2017 to February 2019) at: https://www.macfound.org/fellows/search/all. 
White men account for 520 (51.3\%) of all Fellows, and $81.6 \%$ of all men. White women account for 295 (29.1\%) of all Fellows, and 78.3\% of all women. Blacks account for 127 (12.5\%) of all Fellows. Black men account for 73 (7.2\%) of all Fellows, and $11.5 \%$ of all men. Black women account for 54 (5.3\%) of all Fellows, and $14.3 \%$ of all women. Asians account for 60 (5.9\%) of all Fellows. Asian men account for $40(3.9 \%)$ of all Fellows, and $6.3 \%$ of all men. Asian women account for $20(1.98 \%)$ of all Fellows, and $5.3 \%$ of all women. Native Americans account for $12(1.2 \%)$ of all Fellows. Native American women account for $8(0.8 \%)$ of all Fellows, and $2.1 \%$ of all women. Native American men account for $4(0.4 \%)$ of all Fellows, and $0.6 \%$ of all men (Table 1 ).

An ancestral breakdown of Asians reveals that, of the 60 Fellows, 18 (30\%) are Indian men; 16 (26.7\%) are Chinese men; 12 (20\%) are Chinese women; 3 (5\%) each are Japanese and Pakistani women; 2 (3.3\%) each are Japanese and Vietnamese men; and $1(1.7 \%)$ each is a Cambodian man, a South Korean man, and a Vietnamese woman (Compiled from Table 2). It is important to note that while it is surprising that no Indian woman with ancestry from India has been selected by 2018, in 2019, of the 26 individuals selected as Fellows, one is an Indian woman (“2019 MacArthur Fellows,” 2019).

\subsection{Earned Highest/Terminal Higher Education Degrees of MacArthur Fellows, 1981 to 2018, by Sex and Race}

Table 2 presents data on the number of terminal or highest college degrees earned by Macarthur Fellows. Of the 1014, data for degrees are available for 928 (91.5\%) Fellows, who earned a total of 965 terminal or highest college degrees. There are 37 Fellows who earned two degrees each. Of the 637 male Fellows, $566(88.9 \%)$ earned 593 terminal or highest college degrees: 468 (90\%) out of 520 White men, earned 490 degrees; 58 (79.5\%) out of 73 Black men, earned 60 degrees; 36 (90\%) out of 40 Asian men, earned 39 degrees; and 4 Native American men earned 1 degree each. Of the 377 female Fellows, 362 (92\%) earned 372 terminal or highest college degrees: 287 (97.3\%) out of 295 White women, earned 293 degrees; 48 (88.9\%) out of 54 Black women, earned 50 degrees; 19 (95\%) out of 20 Asian women, earned 21 degrees; and all $8 \mathrm{Na}$ tive American women earned 1 degree each. Of the 22 White male Fellows who earned 2 degrees each, 1 earned two bachelor's degrees (BA/BA); 6 earned two master's degrees each (6 MA degrees, 2 MS degrees, 1 M.ED., M.F.A., M.P.A., and M.B.A. each); 4 earned a JD; 5 earned an MD; and 21 earned a doctoral degree. Two Black men earned 2 bachelor's degrees each; and 3 Asian men earned 2 degrees each ( 1 earned 2 MA degrees, 1 earned an MD and a Ph.D., and 1 earned a Ph.D. and a D.Sc.). Of the 6 White women who earned 2 degrees each, 1 earned 2 bachelor's degrees, 4 earned 2 master's degrees, and 1 earned a Ph.D. and an MD; 2 Black women earned 2 degrees each ( 1 earned 2 master's degrees and 1 earned 2 Ph.D.s); and 2 Asian women earned 2 master's degrees each. 
Table 2. Earned highest/terminal higher education degree of macarthur fellows, 1981 to 2018, by sex and race.

\begin{tabular}{|c|c|c|c|c|c|c|c|c|c|c|c|c|c|c|}
\hline Degree/Type & All & $\begin{array}{c}\% \\
\text { Total }\end{array}$ & Men & $\begin{array}{c}\% \\
\text { Total }\end{array}$ & Women & $\begin{array}{c}\% \\
\text { Total }\end{array}$ & WM & Ww & $\mathrm{BM}$ & BW & $\mathrm{AM}$ & AW & NAM & NAW \\
\hline \multicolumn{15}{|l|}{ Associate } \\
\hline A.A. & 1 & 33.3 & & & 1 & 50 & & & & 1 & & & & \\
\hline A.S. & 1 & 33.3 & & & 1 & 50 & & & & & & & & 1 \\
\hline Diploma & 1 & 33.3 & 1 & 100 & & & & & 1 & & & & & \\
\hline Total & 3 & 100 & 1 & 100 & 2 & 100 & & & 1 & 1 & & & & 1 \\
\hline$\%$ of all Degrees & & & 0.1 & & 0.2 & & & & 0.1 & 0.1 & & & 0.0 & 0.1 \\
\hline \multicolumn{15}{|l|}{ Bachelor } \\
\hline A.B. & 8 & 5.6 & 5 & 3.5 & 3 & 2.1 & 5 & 2 & & 1 & & & & \\
\hline B.A. & 92 & 63.9 & 54 & 37.5 & 38 & 26.4 & 42 & 30 & 10 & 5 & 2 & 1 & & 2 \\
\hline B.Arch. & 4 & 2.8 & 3 & 2.1 & 1 & 0.7 & 3 & 1 & & & & & & \\
\hline B.E.E. & 1 & 0.7 & 1 & 0.7 & & & 1 & & & & & & & \\
\hline B.F.A. & 12 & 8.3 & 9 & 6.3 & 3 & 2.1 & 5 & 2 & 4 & 1 & & & & \\
\hline B.M. & 4 & 2.8 & 2 & 1.4 & 2 & 1.4 & 1 & 1 & 1 & 1 & & & & \\
\hline B.S. & 15 & 10.4 & 11 & 7.6 & 4 & 2.8 & 8 & 3 & 2 & 1 & 1 & & & \\
\hline B.Sc. & 1 & 0.7 & 1 & 0.7 & & & 1 & & & & & & & \\
\hline L.L.B. & 5 & 3.5 & 4 & 2.8 & 1 & 0.7 & 4 & & & 1 & & & & \\
\hline B.Mus. & 1 & 0.7 & & & 1 & 0.7 & & 1 & & & & & & \\
\hline B.Phil. & 1 & 0.7 & & & 1 & 0.7 & & 1 & & & & & & \\
\hline Total & 144 & 100 & 90 & 62.6 & 54 & 37.6 & 70 & 41 & 17 & 10 & 3 & 1 & & 2 \\
\hline$\%$ of all Degrees & 15 & & 9.3 & & 5.6 & & 7.3 & 4.2 & 1.8 & 1.0 & 0.3 & 0.1 & 0.0 & 0.2 \\
\hline Licenciatura & 1 & 100 & & & 1 & 100 & & 1 & & & & & & \\
\hline$\%$ of all Degrees & 0.1 & & & & 0.1 & & & 0.1 & & & & & & \\
\hline \multicolumn{15}{|l|}{ Master's } \\
\hline A.M. & 1 & 0.5 & 1 & 0.5 & & & 1 & & & & & & & \\
\hline M. Mus. & 1 & 0.5 & 1 & 0.5 & & & 1 & & & & & & & \\
\hline M.A. & 77 & 37.9 & 48 & 23.6 & 29 & 14.3 & 38 & 25 & 5 & 4 & 4 & & 1 & \\
\hline M.B.A. & 3 & 1.5 & 2 & 0.9 & 1 & 0.5 & 1 & & 1 & & & & & 1 \\
\hline M.ED & 6 & 3 & 1 & 0.5 & 5 & 2.5 & 1 & 3 & & 2 & & & & \\
\hline M.F.A. & 75 & 36.9 & 29 & 14.4 & 46 & 22.7 & 15 & 30 & 13 & 11 & 1 & 4 & & 1 \\
\hline M.M. & 3 & 1.5 & 2 & 0.9 & 1 & 0.5 & & 1 & 1 & & 1 & & & \\
\hline M.P.A. & 4 & 2 & 3 & 1.5 & 1 & 0.5 & 3 & 1 & & & & & & \\
\hline M.P.H. & 1 & 0.5 & 1 & 0.5 & & & 1 & & & & & & & \\
\hline M.R.P. & 1 & 0.5 & 1 & 0.5 & & & & & & & & & 1 & \\
\hline M.S. & 19 & 9.4 & 13 & 6.4 & 6 & 3.0 & 12 & 4 & 1 & & & 2 & & \\
\hline M.S.W. & 2 & 0.9 & 1 & 0.5 & 1 & 0.5 & & 1 & 1 & & & & & \\
\hline M.Sc. & 2 & 0.9 & 1 & 0.5 & 1 & 0.5 & 1 & & & & & & & 1 \\
\hline
\end{tabular}




\section{Continued}

\begin{tabular}{|c|c|c|c|c|c|c|c|c|c|c|c|c|c|c|}
\hline M.U.P. & 1 & 0.5 & 1 & 0.5 & & & & & 1 & & & & & \\
\hline A.D.V. & 1 & 0.5 & 1 & 0.5 & & & 1 & & & & & & & \\
\hline M.A.T. & 1 & 0.5 & & & 1 & 0.5 & & 1 & & & & & & \\
\hline M.Arch. & 1 & 0.5 & & & 1 & 0.5 & & 1 & & & & & & \\
\hline M.L.A. & 1 & 0.5 & & & 1 & 0.5 & & 1 & & & & & & \\
\hline M.P.S. & 1 & 0.5 & & & 1 & 0.5 & & 1 & & & & & & \\
\hline M.S.E. & 1 & 0.5 & & & 1 & 0.5 & & 1 & & & & & & \\
\hline M.St. & 1 & 0.5 & & & 1 & 0.5 & & 1 & & & & & & \\
\hline Total & 203 & 100 & 106 & 52 & 97 & 48 & 75 & 71 & 23 & 17 & 6 & 6 & 2 & 3 \\
\hline$\%$ of all Degrees & 21 & & 11.0 & & 10.1 & & 7.8 & 7.4 & 2.4 & 1.8 & 0.6 & 0.6 & 0.2 & 0.3 \\
\hline C.Phil. & 1 & 100 & 1 & 100 & & & 1 & & & & & & & \\
\hline$\%$ of all Degrees & 0.1 & & 0.1 & & & & 0.1 & & & & & & & \\
\hline J.D. & 36 & 100 & 17 & 47.2 & 19 & 52.8 & 13 & 14 & 2 & 4 & 2 & 1 & & \\
\hline$\%$ of all degrees & 3.7 & & 1.8 & & 2.0 & & 1.3 & 1.5 & 0.2 & 0.4 & 0.2 & 0.1 & & \\
\hline M.D. & 37 & 100 & 27 & 73 & 10 & 27 & 21 & 6 & 3 & 4 & 3 & & & \\
\hline$\%$ of all Degrees & 3.8 & & 2.8 & & 1.0 & & 2.2 & 0.6 & 0.3 & 0.4 & 0.3 & & & \\
\hline \multicolumn{15}{|l|}{ Doctorate } \\
\hline D.M.A. & 2 & 0.37 & 2 & 0.37 & & & 1 & & 1 & & & & & \\
\hline D.Min. & 1 & 0.19 & 1 & 0.19 & & & & & 1 & & & & & \\
\hline D.Mus. & 1 & 0.19 & 1 & 0.19 & & & 1 & & & & & & & \\
\hline Doc. des Lettres & 1 & 0.19 & 1 & 0.19 & & & 1 & & & & & & & \\
\hline Doctorat de Sociologie & 1 & 0.19 & 1 & 0.19 & & & 1 & & & & & & & \\
\hline D. Sc. & 2 & 0.37 & 2 & 0.37 & & & 1 & & & & 1 & & & \\
\hline D.P.H & 1 & 0.19 & 1 & 0.19 & & & 1 & & & & & & & \\
\hline D.Phil. & 9 & 1.7 & 8 & 1.5 & 1 & 0.19 & 8 & 1 & & & & & & \\
\hline Ph.D. & 514 & 95.2 & 331 & 61.3 & 183 & 33.9 & 293 & 157 & 12 & 12 & 24 & 13 & 2 & 1 \\
\hline Kandidat Degree (Ph.D.) & 1 & 0.19 & 1 & 0.19 & & & 1 & & & & & & & \\
\hline Sc.D. & 1 & 0.19 & 1 & 0.19 & & & 1 & & & & & & & \\
\hline Th.D. & 1 & 0.19 & 1 & 0.19 & & & 1 & & & & & & & \\
\hline Ed.D. & 4 & 0.7 & & & 4 & 0.7 & & 2 & & 2 & & & & \\
\hline D.Ed. & 1 & 0.19 & & & 1 & 0.19 & & & & & & & & 1 \\
\hline Total & 540 & 100 & 351 & 65 & 189 & 35.0 & 310 & 160 & 14 & 14 & 25 & 13 & 2 & 2 \\
\hline$\%$ of all Degrees & 56 & & 36.4 & & 19.6 & & 32.1 & 16.6 & 1.5 & 1.5 & 2.6 & 1.3 & 0.2 & 0.2 \\
\hline All Degrees & 965 & & 593 & 61.5 & 372 & 38.5 & 490 & 293 & 60 & 50 & 39 & 21 & 4 & 8 \\
\hline Percent & & & & & & & 50.8 & 30.4 & 6.2 & 5.2 & 4.0 & 2.2 & 0.4 & 0.8 \\
\hline
\end{tabular}

Note: $\mathrm{WM}=$ White men; $\mathrm{WW}=$ White women; $\mathrm{BM}=$ Black men; $\mathrm{BW}=$ Black women; $\mathrm{AM}=$ Asian men; AW = Asian women; NAM = Native American men; NAW = Native American women. Source: Compiled and computed based on data provided by the MacArthur Fellowship Program (June 2017 to February 2019) at: https://www.macfound.org/fellows/search/all. 
According to Table 2, of the 965 terminal or highest college degrees earned by 928 Fellows, 540 (56\%) are doctorates ( 351 by men and 189 by women), with 514 (53.3\% of 965 total) being Ph.D.s.; 203 (21\%) are master's degrees (106 by men and 97 by women), including 77 (8\% of 965) M.A. degrees, 75 (7.8\%\% of 965) M.F.A. degrees, and 19 (2\% of 965) M.S. degrees; 144 (15\%) are bachelor's degrees ( 90 by men and 54 by women), including 92 (9.5\% of 965) B.A. degrees, 15 (1.6\% of 965) B.S. degrees, and 12 (1.2\% of 965) B.F.A. degrees; 37 (3.8\% of 965) M.D.s (27 by men and 10 by women); 36 (3.7\% of 965) JDs (19 by women and 17 by men); 3 ( $0.3 \%$ of 965) Diplomas/Associate degrees (1 Black woman, 1 Native American woman, and 1 Black man); 1 (0.1\%) Licenciatura (a White woman) and $1(0.1 \%)$ C.Phil. degree (a White man).

Of the 965 total degrees earned, 490 (50.8\%) are earned by White men; 293 (30.4\%) are earned by White women; 60 (6.2\%) are earned by Black men; 50 (5.2\%) are earned by Black women; 39 (4\%) are earned by Asian men; 21 (2.2\%) are earned by Asian women; 8 (0.8\%) are earned by Native American women; and $4(0.4 \%)$ are earned by Native American men. Of the 540 doctoral degrees earned, 310 (57.4\%, but $32.1 \%$ of total) are earned by White men; 160 (29.6\%, but $16.6 \%$ of total) are earned by White women; 14 (2.6\%, but $1.5 \%$ total) each are earned by Black men and Black women; 25 (4.6\%, but $2.6 \%$ of total) are earned by Asian men; 13 (2.4\%, but $1.3 \%$ or total) are earned by Asian women; and $2(0.4 \%$, but $0.2 \%$ of total $)$ each are earned by Native American men and Native American women. Of the 37 Doctor of Medicine degrees (MD) earned, $21(56.8 \%)$ are earned by White men; $6(16.2 \%)$ are earned by White women; 4 (10.8\%) are earned by Black women; and 3 (8.1\%) each are earned by Asian men and Black men. Of the 36 Juris Doctor (JD) degrees earned, 14 (38.9\%) are earned by White women; 13 (36\%) are earned by White men; 4 (11.1\%) are earned by Black women; 2 (5.6\%) each are earned by Asian men and Black men; and $1(2.8 \%)$ is earned by an Asian woman. Of the 203 master's degrees earned, $75(36.9 \%)$ are earned by White men; 71 (35\%) are earned by White women; 23 (11.3\%) are earned by Black men;17 (8.4\%) are earned by Black women; 6 (3\%) each are earned by Asian men and Asian women; 3 (1.5\%) are earned by Native American women; and 2 (1\%) are earned by Native American men. Of the 144 bachelor's degrees earned, 70 (48.6\%) are earned by White men; 41 (28.5\%) are earned by White women; $17(11.8 \%)$ are earned by Black men; 10 (6.9\%) are earned by Black women; 3 (2.1\%) are earned by Asian men; 2 (1.4\%) are earned by Native American women; and 1 (0.7\%) is earned by an Asian woman (Table 2).

\subsection{Alma Mater of Highest/Terminal Higher Education Degrees and Types of Degrees Earned by MacArthur Fellows, 1981 to 2018, by Sex and Race}

The alma mater or higher education institution where an individual earns their degree plays an important role in that person's success in the United States and the world. This is also the case when it comes to those selected for the MacAr- 
thur Fellowship. This has also been observed in other studies focusing on prominent individuals from many walks of life (Kaba, 2012b, 2013ab, 2015, 2016, 2017a). The MacArthur Fellowship Program conducted a study on the alma mater of its Fellows focusing on first degrees, especially bachelor's degrees. The study finds that from 1981 to 2014, the MacArthur Fellowship Program selected 918 Fellows, who attended 315 diverse higher education institutions. Of the 918 Fellows, $34 \%$ attended private research universities; $23 \%$ attended public universities; $14 \%$ attended private liberal arts colleges; $11 \%$ or 100 did not earn an undergraduate degree; $10 \%$ attended international higher education institutions; $4 \%$ attended private master's level and/or professional focused institutions; 3\% attended special focus institutions; and $1 \%$ attended community/two-year institutions. There were 44 (4.8\%) Fellows who attended women's colleges and universities, 40 (4.4\%) Fellows attended religiously affiliated universities, and 15 (1.6\%) Fellows attended historically Black colleges and universities or tribal colleges. Of the 100 Fellows that did not earn an undergraduate degree, 39 attended college but did not complete their program of study, 37 did not participate in higher education studies, and 24 did not complete their undergraduate degrees, but hold advanced graduate degrees (Conrad, 2017).

The information on the state and region in the United States, country, and world region where a Fellow's alma matter is located is also very important because these entities tend to compete for talent (Hernandez, 2013; Kaba, 2012b, 2013ab, 2015, 2016, 2017a). This current study focuses on the terminal or highest degrees of MacArthur Fellows, including the state and region in the United States where the institution is located, the country outside the United States where the institution is located, and the world region where the country is located.

According to Table A1 (in appendices section), of the 965 terminal or highest degrees earned by MacArthur Fellows from 232 institutions from 1981 to 2018, $865(89.6 \%)$ are earned from $174(75 \%)$ institutions in the United States, and 100 degrees (10.4\%) are earned from 58 (25\%) institutions outside of the United States. Of the 865 degrees earned in the United States, 516 (59.7\%) are earned by men, and 349 (40.3\%) are earned by women: 424 (49\%, but $43.94 \%$ of 965 total) are White men; 275 (31.8\%, but $28.5 \%$ of total) are White women; 55 (6.4\%, but $5.7 \%$ of total) are Black men; 47 (5.4\%, but $4.9 \%$ of total) are Black women; 33 (3.8\%, but $3.4 \%$ of total) are Asian men; 19 (2.2\%, but $2 \%$ of total) are Asian women; 8 (0.92\%, $0.83 \%$ of total) are Native American women; and 4 (0.5\%, but $0.4 \%$ of total) are Native American men.

Of the 865 degrees earned in the United States, 475 (54.9\%, but $49.2 \%$ of 965 total) are earned at institutions in the Northeast ( 280 by men and 195 by women); 187 (21.6\%, but $19.4 \%$ of total) degrees earned in the West (120 men and 67 women);115 (13.3\%, but 11.9\% of total) degrees earned in the Midwest (70 men and 45 women); and 88 (10.2\%, but $9.1 \%$ of total) degrees are earned in the South ( 46 by men and 42 by women). 
Of the 475 degrees earned from 70 institutions in the Northeast, 228 (48\%, but $26.4 \%$ of U.S. total) are earned by White men; 156 (32.8\%, but $18 \%$ of U.S. total) are earned by White women; 33 (6.9\%, but $3.8 \%$ of U.S. total) are earned by Black men; 27 (5.7\%, but $3.1 \%$ of U.S. total) are earned by Black women; 17 (3.6\%, but $2 \%$ of total) are earned by Asian men; 11 (2.3\%, but $1.3 \%$ of U.S. total) are earned by Asian women; 2 ( $0.4 \%$, but $0.2 \%$ of U.S. total) are earned by Native American men; and $1(0.2 \%$, but $0.1 \%$ of total) is earned by a Native American woman. Of the 187 degrees earned from 40 institutions in the West, 98 (52.4\%, but $11.3 \%$ of U.S. total) are earned by White men; 52 (27.8\%, but $6 \%$ of U.S. total) are earned by White women; 11 (5.9\%, but $1.3 \%$ of U.S. total) are earned by Black men; 4 (2.1\%, but $0.46 \%$ of U.S. total) are earned by Black women; 10 (5.4\%, but $1.2 \%$ of U.S. total) are earned by Asian men; 5 (2.7\%, 0.6\% of U.S. total) are earned by Asian women; 6 (3.2\%, but $0.7 \%$ of U.S. total) are earned by Native American women; and 1 ( $0.5 \%$, but $0.12 \%$ of U.S. total) is earned by a Native American man.

Of the 115 degrees earned from 25 institutions in the Midwest, 59 (51.3\%, but $6.8 \%$ of U.S. total) are earned by White men; 36 (31.3\%, but $4.2 \%$ of U.S. total) are earned by White women; 6 (5.2\%, but $0.7 \%$ of U.S. total) are earned by Black women; 5 ( $4.3 \%$, but $0.6 \%$ of U.S. total) each are earned by Asian men and Black men; 3 (2.6\%, but $0.4 \%$ of U.S. total) are earned by Asian women; and 1 (0.9\%, but $0.12 \%$ of U.S. total) is earned by a Native American man. Of the 88 degrees earned from 39 institutions in the South, 39 (44.3\%, but $4.5 \%$ of U.S. total) are earned by White men; 31 (35.2\%, but $3.6 \%$ of U.S. total) are earned by White women; 10 (11.4\%, but $1.2 \%$ of U.S. total) are earned by Black women; 6 (6.8\%, but $0.7 \%$ of U.S. total) are earned by Black men; and 1 (2.3\%, but $0.12 \%$ of U.S. total) each is earned by an Asian man and a Native American woman.

Examining the top 10 states that awarded the most degrees, the state of Massachusetts awarded the most number of degrees (176) from 17 institutions (107 degrees earned by men and 69 degrees earned by women); California awarded 155 degrees from 22 institutions (103 degrees earned by men and 52 degrees earned by women). New York state awarded 139 degrees from 32 institutions (76 degrees earned by men and 63 degrees earned by women); Connecticut awarded 66 degrees from 3 institutions (39 degrees earned by men and 27 degrees earned by women); New Jersey awarded 48 degrees from 4 institutions (33 degrees earned by men and 15 degrees earned by women); Illinois awarded 41 degrees from 6 institutions (31 degrees earned by men and 10 degrees earned by women); Maryland awarded 24 degrees from 3 institutions (13 degrees earned by women and 11 degrees earned by men); Michigan awarded 18 degrees from 5 institutions ( 9 degrees each earned by men and women); Pennsylvania awarded 23 degrees from 7 institutions (16 degrees earned by men and 7 degrees earned by women); and Rhode Island awarded 16 degrees from 2 institutions (10 degrees earned by women and 6 degrees earned by men).

The following institutions awarded 10 or more degrees: Harvard University, 
119 degrees (13.8\% of U.S. total, but $12.3 \%$ of all degrees); Yale University, 61 degrees (7.1\% of U.S. total, but $6.3 \%$ of all degrees); University of California, Berkeley, 51 degrees (5.9\% of U.S. total, but $5.3 \%$ of all degrees); Columbia University, 44 degrees (5.1\% of U.S. total, but $4.6 \%$ of all degrees); Princeton University, 41 degrees (4.7\% of U.S. total, but $4.2 \%$ of all degrees); Massachusetts Institute of Technology, 32 degrees (3.7\% of U.S. total, but $3.3 \%$ of all degrees); University of Chicago, 24 degrees (2.8\% of U.S. total, but $2.5 \%$ of all degrees); California Institute of Technology, Cornell University, and Stanford University, each 20 degrees (2.3\% of U.S. total, but $2.1 \%$ of all degrees); New York University, 19 degrees (2.2\% of U.S. total, but $2 \%$ of all degrees); University of California, Los Angeles, 17 degrees (1.97\% of U.S. total, but $1.76 \%$ of all degrees); Johns Hopkins University, 16 degrees (1.85\% of U.S. total, but $1.66 \%$ of all degrees); University of Michigan, 14 degrees (1.6\% of U.S. total, but $1.5 \%$ of all degrees); City University of New York, the University of Iowa, the University of Pennsylvania, and the University of Washington, each 12 degrees (1.4\% of U.S. total, but $1.2 \%$ of all degrees); University of Wisconsin, Madison, 11 degrees (1.3\% of U.S. total, but $1.1 \%$ of all degrees); and the University of California, San Francisco, 10 degrees (1.2\% of U.S. total, but $1 \%$ of all degrees).

Of the 100 degrees awarded to Fellows at 58 institutions outside of the United States, $78(78 \%)$ are earned at 37 institutions in Europe (63 degrees earned by men and 15 degrees earned by women); 18 degrees earned at 17 institutions in Western Europe (16 by men and 2 by women); 48 degrees earned at 11 institutions in Northern Europe ( 35 by men and 13 by women); 11 degrees earned at 8 institutions in Eastern Europe (all 11 are men); and 1 degree earned in Southern Europe. There are 7 degrees earned at 7 institutions in Asia (5 men and 2 women); 4 degrees earned in Eastern Asia (3 men and 1 woman); and 3 degrees earned in Western Asia ( 2 men and 1 woman). There are 5 degrees earned at 4 institutions in Canada ( 3 by men and 2 women). There are 5 degrees earned at 5 institutions in Latin America and the Caribbean ( 3 men and 2 women); 2 degrees earned in the Caribbean ( 2 men); 2 degrees earned in South America (1 man and 1 woman); and 1 degree earned by a woman in Central America. There are 3 degrees earned at 3 institutions in Oceania (Australia, all men). There are 2 women who earned a degree each in Africa (Egypt and Nigeria) (Table A1 in appendices section).

\section{Discussion}

The statistics on the MacArthur Fellows presented above have provided to the public a better understanding of the demographic, educational and professional backgrounds of these geniuses. The data illustrated that while White men accounted for the majority of Fellows selected from 1981 to 2018, women and minorities have substantially increased their overall proportions. In fact, since the data show that those selected to be Fellows are aged 18 and older, the $12.5 \%$ of Blacks and the $5.9 \%$ of Asians in Table 1 are almost their adult proportions in 
the general population of the United States. For example, of the 249.2 million people in the United States aged 18 and over in 2018, 13.3\% were Black and 6.2\% were Asian ("Table 1. Educational Attainment of the Population 18 Years and Over, by Age, Sex, Race, and Hispanic Origin: 2018," 2019). The 1.995 million Native Americans aged 18 and over in 2017 is $0.8 \%$ of the 247.4 million people aged 18 and over in the United States in that year ("ACS Demographic and Housing Estimates, 2017," 2020.; "Selected Population Profile in the United States: 2017 American Community Survey 1 Year-Estimates," 202).

However, as the data illustrated, the figures have not increase for women, especially Asian, Black, and White women, the way they have increased for minorities. For example, as Table 1 shows, women accounted for 37.2\% of all Fellows selected from 1981 to 2018: 29.1\% of White Women, 5.3\% of Black women, $1.98 \%$ of Asian women, and $0.8 \%$ of Native American women. However, in 2018 , Women accounted for $51.6 \%(128,488,000)$ of people aged 18 and over in the United States: $32.5 \%(81,060,000)$ for non-Hispanic White women, $7.2 \%$ $(18,035,000)$ for Black women, and 3.3\% $(8,162,000)$ for Asian women ("Table 1. Educational Attainment of the Population 18 Years and Over, by Age, Sex, Race, and Hispanic Origin: 2018," 2019). These findings are consistent with other studies of prominent people in the United States, including some in this current study, whereby for the most part, regardless of race, women are a visible minority (Coutu, 2007; “'Honey, You Got a MacArthur': Blacks Who Have Received the Coveted Genius Grant,” 1997; Kaba, 2012b, 2013ab, 2015, 2016, 2017a; Miller et al., 2018; Pick, 1995; Wooster 2010: p. 43). In an interview with a former Director of the MacArthur Fellowship Program, Daniel J. Socolow, Coutu (2007) brought up this issue as to whether it tends to be a challenge for women to win the MacArthur Fellowship. Socolow then explains that while that is the case the number of women selected as Fellows has gradually increased over the decades as the positions that women hold or the roles that they play in society have changed. He claims that the MacArthur Fellowship Program makes sure that women are well represented, especially as they are just as creative as their male counterparts. Part of the reason why more men are selected as Fellows, according to Socolow, could be due to the career paths that women and men take. Women tend to have competing demands in the society compared to their male counterparts. He notes that the gap in numbers are closing and that at least once during his tenure, the majority of Fellows selected were women (p. 126).

The remaining part of this discussion section will focus on the following: the complex racial categorization in the United States; educational attainment and highest or terminal degrees; educational attainment and academic institutions; and academic institutions and geographic location.

\subsection{Complex Racial Categorization in the United States}

It is important to point out that the method used to define racial categories in the United States is responsible for Whites accounting for over four out of every 
five Fellows in this current study. As noted in the methodology section, most individuals from Arab countries in Asia and Africa are categorized as White in the United States. Individuals from Iran, Israel, Turkey and most central Asian nations are also categorized as White. Individuals from China, Japan, South Korea, India and southeastern Asian nations are categorized as Asian, but if any of them has a child with someone who is categorized as White, such as an Irish person, then that child is White. One such person is categorized as White in this study, instead of Asian (also see Jilani, 2020). This means that the method of racial categorization in the United States tends to hide the Asian population in the country, which then results in those Asian and African nations where people of Asian heritage/DNA have been residing for over 1,400 years, not getting the recognition they deserve, because most people equate White with European. Kaba (2017a) discussed this issue and pointed out that the Barack Obama administration published a notice in the Federal Register entitled: "Standards for Maintaining, Collecting and Presenting Federal Data on Race and Ethnicity" for the public to make comments on the government's intention to create a new racial category in the 2020 U.S. Census called: "Middle Eastern and North African" (MENA). It is reported that this potential racial categorization "... would include anyone from a region of the world stretching from Morocco to Iran, and including Syrian and Coptic Christians, Israeli Jews and other religious minorities" (pp. 105-106).

\subsection{Educational Attainment and Highest or Terminal Degrees}

Educational attainment, especially terminal degrees such as doctoral, MDs, JDs, and to a great extent, master's degrees tend to be the primary factor for the selection of an individual as a MacArthur Fellow. This is especially the case with the Ph.D. degree, which turns out to account for 514 (53.3\%) of the total 965 terminal or highest degrees awarded to 928 Fellows. The 144 (15.9\%) bachelor's degrees earned by 140 Fellows, plus the 3 associate/diploma degrees earned by 3 Fellows, which combined for 147 degrees account for $15.2 \%$ of all 965 degrees awarded. It is important to note that while earning a college degree, especially a terminal degrees is a big factor that determines an individual's selection to become a MacArthur Fellow, as discussed Table 2 by the Fellowship program itself, a substantial proportion of Fellows did not earned a college degree or did not attend college altogether. This brings us to the terms genius and creativity discussed in the conceptual definition section of this study. While the media and the general public identify the Fellows as geniuses, the MacArthur Fellowship program uses the term creative to describe them. In fact, the title of the 2019 announcement of the new Fellows has the word creative in it: "Meet the 2019 Macarthur Fellows: 26 Extraordinarily Creative People Who Inspire Us All." (https://www.macfound.org/videos/650/). This means that both the public and the MacArthur Fellowship program appreciate talented or highly skilled individuals, regardless of whether they earned a college degree or not. 
Although earning a terminal degree increases a person's chances of being selected as a MacArthur Fellow, in the United States in particular, the higher education institutions where Fellows earned their degrees can be argued to be far more important than the degree itself. Table 3 substantiates this argument. For example, the eight Ivy league institutions combined (Brown University, Columbia University, Cornell University, Dartmouth College, Harvard University, Princeton University, the University of Pennsylvania, and Yale University) in the United States awarded 306 (31.7\%) of the total 965 degrees to 300 Fellows (32.3\% of 928 Fellows) (190 degrees earned by 185 men, and 116 degrees earned by 115 women): 2 White men had 2 degrees each from Harvard University; 1 White man had 2 degrees from the University of Pennsylvania; 1 White man had 1 degree each from Princeton University and Yale University; and 1 Asian man and 1 White woman each had 2 degrees from Harvard University (Table 3; also see Benzon, 2018: pp. 4 \& 7; Wooster, 2010: p. 42). Writing about the predominance of Princeton University among MacArthur Fellows despite having a total student enrollment of only 8213 (undergraduate and graduate) as of November 30,2019, on its website, Wooster (2010) notes that: "For some reason, an inordinate number of fellowships had been awarded to scholars at Princeton University, including seven in the first two years. By 1987, five MacArthur Fellows-physicist Joseph H. Taylor, historian Robert Darnton, physicist Edward Witten, astrophysicist James Gunn, and physicist David Gross-were all Princeton professors ..." (p. 42).

A substantial number of institutions ranked in the U.S. News and World Report Top 50 to 75 national universities tend to have awarded 10 or more highest or terminal degrees to the Fellows in this current study. For example, the following top 25 institutions ranked in the 2020 U.S. News and World Report

Table 3. Number of highest or terminal degrees awarded by ivy league institutions to Macarthur fellows, 1981-2018. ( $\mathrm{n}=306$ degrees awarded to 300 Fellows).

\begin{tabular}{cccccc}
\hline Institution & $\begin{array}{c}\text { Number of } \\
\text { Degrees }\end{array}$ & Men & $\begin{array}{c}\text { \% of Ivy } \\
\text { League Total }\end{array}$ & Women & $\begin{array}{c}\text { \% of Ivy } \\
\text { League Total }\end{array}$ \\
\hline Brown University & 7 & 3 & 0.98 & 4 & 1.3 \\
Columbia University & 44 & 26 & 8.5 & 18 & 5.9 \\
Cornell University & 20 & 12 & 3.9 & 8 & 2.6 \\
Dartmouth College & 2 & 1 & 0.33 & 1 & 0.33 \\
Harvard University & 119 & 79 & 25.8 & 40 & 13.1 \\
Princeton University & 41 & 27 & 8.8 & 14 & 4.6 \\
$\begin{array}{c}\text { University of } \\
\text { Pennsylvania }\end{array}$ & 12 & 8 & 2.6 & 4 & 1.3 \\
Yale University & 61 & 34 & 11.1 & 27 & 8.8 \\
Total & 306 & 190 & 62.1 & 116 & 37.9 \\
\hline
\end{tabular}

Source: (Compiled and computed from Table A1). 
national rankings awarded 522 (54.1\% of 965 degrees) degrees to 514 Fellows (55.4\% of the 928 Fellows with highest or terminal degrees in this study) in this study: (\#1) Princeton University (41 Fellows earned 42 degrees); (\#2) Harvard University (115 Fellows earned 119 degrees, with 4 Fellows earning two degrees each, including 2 White men, 1 Asian man, and 1 White woman); (\#3) Columbia University (44 Fellows earned 44 degrees), Massachusetts Institute of Technology (32 Fellows earned 32 degrees), and Yale University (61 Fellows earned 61 degrees) tie; (\#6) Stanford University (20 Fellows earned 20 degrees), the University of Chicago (23 Fellows earned 24 degrees, including 1 White male who earned two degrees), and the University of Pennsylvania (11 Fellows earned 12 degrees, including 1 White male who earned 2 degrees) tie; (\#9) Northwestern University (5 Fellows earned 5 degrees); (\#10) Duke University (6 Fellows earned 6 degrees) and Johns Hopkins University (15 Fellows earned 16 degrees, including 1 White male who earned 2 degrees) tie; (\#12) California Institute of Technology (20 Fellows earned 20 degrees) and Dartmouth College (2 Fellows earned 2 degrees) tie; (\#14) Brown University (7 Fellows earned 7 degrees); (\#15) University of Notre Dame (no Fellow from this institution) and Vanderbilt University (2 Fellows earned 2 degrees) tie; (\#17) Cornell University (20 Fellows earned 20 degrees) and Rice University (no Fellow from this institution) tie; (\#19) Washington University in St. Louis (no Fellow from this institution); (\#20) University of California, Los Angeles (17 Fellows earned 17 degrees); (\#21) Emory University (1 Fellow earned a degree); (\#22) University of California, Berkeley (51 Fellows earned 51 degrees) and the University of Southern California (4 Fellows earned 4 degrees) tie; (\#24) Georgetown University (1 Fellow earned a degree); and (\#25) Carnegie Mellon University (2 Fellows earned 2 degrees) and the University of Michigan, Ann Arbor (14 Fellows earned 14 degrees) tie (Table 4; also see Benzon, 2018: pp. 4 \& 7).

\subsection{Geographic Location of Higher Education Institutions Where MacArthur Fellows Earned Their Highest or Terminal Degrees}

This brings us to the geographic location such as the U.S. state and region, country, and world region where an institution is located. This is a very important information that helps one to understand the selection of an individual as a Fellow. It is not a co-incidence that all eight ivy league institutions are located in the Northeast region of the United States, or that a substantial number of degrees (155 degrees) were awarded in California alone. The Northeast and the West, especially California tend to have relatively high numbers of Fellows partly because of their wealth, with New York, Massachusetts and New Jersey leading the way in the Northeast. The wealthier a state and its region are, the more likely that they have significant numbers of top ranked colleges and university. This is because top ranked institutions tend to have relatively high endowments. For example, Kaba's (2016) study finds that: “.... the endowment data provided by the US Department of Education for the 120 institutions in the US with the 
Table 4. Top 25 U.S. news and world report national universities and their graduates selected as Macarthur fellows, 1981-2018.

\begin{tabular}{|c|c|c|c|}
\hline 2020 U.S. News Rank & Institution & \# of Fellows & \# of Degrees \\
\hline 1 & Princeton University & 41 & 42 \\
\hline 2 & Harvard University & 115 & 119 \\
\hline 3 & Columbia University & 44 & 44 \\
\hline 3 & Massachusetts Institute of Technology & 32 & 32 \\
\hline 3 & Yale University & 61 & 61 \\
\hline 6 & Stanford University & 20 & 20 \\
\hline 6 & University of Chicago & 23 & 24 \\
\hline 6 & University of Pennsylvania & 11 & 12 \\
\hline 9 & Northwestern University & 5 & 5 \\
\hline 10 & Duke University & 6 & 6 \\
\hline 10 & Johns Hopkins University & 15 & 16 \\
\hline 12 & California Institute of Technology & 20 & 20 \\
\hline 12 & Dartmouth College & 2 & 2 \\
\hline 14 & Brown University & 7 & 7 \\
\hline 15 & University of Notre Dame & 0 & 0 \\
\hline 15 & Vanderbilt University & 2 & 2 \\
\hline 17 & Cornell University & 20 & 20 \\
\hline 17 & Rice University & 0 & 0 \\
\hline 19 & Washington University in St. Louis & 0 & 0 \\
\hline 20 & University of California, Los Angeles & 17 & 17 \\
\hline 21 & Emory University & 1 & 1 \\
\hline 22 & University of California, Berkeley & 51 & 51 \\
\hline 22 & University of Southern California & 4 & 4 \\
\hline 24 & Georgetown University & 1 & 1 \\
\hline 25 & Carnegie Mellon University & 2 & 2 \\
\hline 25 & University of Michigan, Ann Arbor & 14 & 14 \\
\hline Total & & 514 & 522 \\
\hline
\end{tabular}

Source: Compiled and computed from Table A1; and “National University Rankings, 2020,” 2019.

highest endowments in 2007 was $\$ 322.2$ billion. The total for the eight Ivy League institutions in 2007 was $\$ 98.7$ billion (30.6\% of the $\$ 322.2$ billion): Harvard University ( $\$ 34.6$ billion); Yale University ( $\$ 22.5$ billion); Princeton University ( $\$ 15.8$ billion); Columbia University ( $\$ 7.15$ billion); University of Pennsylvania ( $\$ 6.64$ billion); Cornell University ( $\$ 5.425$ billion); Dartmouth College ( $\$ 3.76$ billion); and Brown University ( $\$ 2.78$ billion) (p.24). In California, in 2007, Stanford University alone had an endowment of $\$ 17.16$ billion, and the California Institute of Technology, $\$ 1.86$ billion (Kaba, 2012a: p.28). The massive financial 
wealth of a university is also connected to the age of an institution. Kaba's (2012a) study also finds that the older an institution is, the more likely that it is highly ranked, and the more likely that it has a large endowment. For example, Ivy league institutions are among the oldest higher education institutions in the United States, with Harvard University established in 1636, Yale University in 1701, and Princeton University in 1746 (p. 27).

These explanations in the paragraph above tend to apply for the most part to the countries with institutions that awarded highest or terminal degrees to the Fellows in this current study. As Table A1 illustrates, The United Kingdom (8 institutions awarded 45 degrees), Germany (7 institutions awarded 8 degrees), and France ( 5 institutions awarded 5 degrees) have a significant number of institutions that awarded dozens of degrees to MacArthur Fellows. For example, the University of Oxford (established in 1096) awarded 18 degrees, the University of Cambridge (established in 1209) awarded 15 degrees, and the University of London (established in 1836) awarded 5 degrees. The University of Oxford is reported to have an endowment of 3.4 billion British pounds in 2007, and the University of Cambridge is reported to have an endowment of 4.1 billion British pounds in 2006 (Kaba, 2012a: p. 27). Kaba (2012a) writes of these elite institutions that: "Most of them have not just world-class medical degree programs, but also world class hospitals attached to them. The political, economic, religious, and military elites in most countries of the world are trained at these institutions" (p. 5).

\section{Conclusion}

This study started by discussing the contributions made by various non-governmental organizations that honor or award grants or fellowships to gifted individuals. Some of these organizations require lengthy applications, while some do not require one to apply, but will have committees that would do confidential search for gifted individuals that they select for grants. In the United States, the MacArthur Fellowship Program, established in 1981, has been awarding grants worth hundreds of thousands of dollars with no strings attached to individuals the program selects over a five-year period. Around twenty to twenty-five individuals who are either citizens or residents of the United States are eligible for the award. By 2019, the amount awarded to each Fellow over a five-year period was $\$ 625,000$.

The study presents a conceptual definitions section to explain the term "genius". The media and the public refer to the Fellows as geniuses, while the MacArthur Fellowship Program refers to them as "creative" or uses the term "creativity" when lamenting about them (Conrad, 2014, September 2). Some definitions of the term genius tend to include the word creative or creativity. One common definition of the term genius is a person with "exceptional intellectual or creative power or other natural ability".

The study produced many interesting findings. For example, of the 1014 Fel- 
lows, Whites account for over eight out of every ten, while minorities account for almost 20 percent. Men account for almost 63\%, with White men accounting for 51.3 percent. White women account for $29.1 \%$, followed by Black men, $7.2 \%$, Black women, 5.3\%, Asian men, 3.94\%, Asian women, 1.98\%, Native American women, $0.8 \%$, and Native American men, 0.4 percent. Asians are the youngest Fellows, while Black Fellows are the oldest. Both the youngest and oldest Fellows are White men, and the youngest female Fellow is a Black woman. The mean age for all men is 45.98 years and 45.53 years for women.

Finally, of the 965 terminal or highest degrees earned by 928 Fellows, 540 (56\%) are doctorates, with the Ph.D. accounting for 514 (53.3\%). Of the 965 degrees earned, $490(50.8 \%)$ are earned by White men, 293 (30\%) are earned by White women, $60(6.2 \%)$ are earned by Black men, 50 (5.2\%) are earned by Black women, 39 (4\%) are earned by Asian men, 21 (2.2\%) are earned by Asian women, $8(0.8 \%)$ are earned by Native American women and $4(0.4 \%)$ are earned by Native American men. Harvard University awarded the highest proportion of degrees to MacArthur Fellows with 119, followed by Yale University with 61, UC Berkeley with 51, Columbia University with 44, and Princeton University with 41. All eight Ivy league institutions awarded 306 degrees to 300 Fellows. The 2020 U.S. News and World Report Top 25 institutions combined awarded 522 degrees (54.1\% of 965 total degrees) to 514 Fellows (55.5\% of 928 Fellows with degrees in this study).

The data in this study have revealed that men continue to be overrepresented among those selected as MacArthur Fellows, just as they are overrepresented among those awarded many other prizes to prominent individuals in the United States. As it is already obvious, earning a college degree, especially a terminal degree such as doctoral, $\mathrm{MD}$, or JD, puts a candidate in a position to be selected as a Fellow. It is just in the 1970s that women and minorities were accepted into higher education institutions in significant numbers. It would therefore take significant time to earn bachelor's degrees, and especially so for terminal degrees. However, some minority groups such as Black men and Asian men tend to have higher proportions of Fellows than their proportions in the adult population of the United States.

\section{Conflicts of Interest}

The author declares no conflicts of interest regarding the publication of this paper.

\section{References}

(1997). 'Honey, You Got a MacArthur': Blacks Who Have Received the Coveted Genius Grant. The Journal of Blacks in Higher Education, 17, 66-68.

2019 MacArthur Fellows (2019). MacArthur Fellowship Program. https://www.macfound.org/programs/fellows/

About MacArthur Fellows Program (2019). MacArthur Fellows Program. https://www.macfound.org/programs/fellows/strategy/ 
ACS Demographic and Housing Estimates, 2017 (2020). American Community Survey. United States Census Bureau.

https://data.census.gov/cedsci/table?d=ACS\%205-Year\%20Estimates\%20Data\%20Profi $\underline{\text { les\&table }=\text { DP05\&tid }=\text { ACSDP5Y2017.DP05 }}$

Andrews, D. (2018). The Genius Effect: What Makes One a genius, and Who Can Rightly or Wrongly Claim the Title. Credit Management, 26-27.

Benzon, W. L. (2018). The Genius Chronicles: Going Boldly Where None Have Gone Before.

https://www.academia.edu/7974651/The Genius Chronicles Going Boldly Where N one Have Gone Before

Brinkman, A. (2010). Sudden Genius: Creativity Explored Through Ten Extraordinary Lives (Book Review). Library Journal, 135, 124.

Conrad, C. (2013). 5 Myths about MacArthur 'Genius' Grants. Washington Post. washingtonpost.com/opinions/five-myths-about-the-macarthur-genius-grants/2013/09/20/833963 b8-213f-11e3-b73c-aab60bf735d0_story.html

Conrad, C. (2014). Geography of Geniuses: New Data about MacArthur Fellows Shows Creative People Move More. Time Magazine.

https://time.com/3225774/macarthur-fellows-genius-geography-creative-people-movemore/

Conrad, C. (2017). Does Alma Mater Really Matter? Where MacArthur 'Genius' Fellows Went to College. MacArthur Fellows Program. MacArthur Foundation.

https://www.macfound.org/media/files/MacArthur Fellows Program Article Reprint - Does Alma Mater Really Matter oL0ntBJ.pdf

Coutu, D. (2007). Picking Winners: A Conversation with MacArthur Fellows Program Director Daniel J. Socolow. Harvard Business Review, 45, 121-126.

Cox, J., \& Daniel, N. (1984). The MacArthur Fellows Look Back. Gifted Child Today, 35, 18-25. https://doi.org/10.1177/107621758400700608

Epstein, J. (2013). I Dreamed of Genius: A Consideration of the Most Elusive Human Quality. Commentary.

https://www.commentarymagazine.com/articles/i-dream-of-genius/

Fellows Location at Award (2018). MacArthur Fellowship Program. https://www.macfound.org/maps/2/

Fellows Location at Birth (2018). MacArthur Fellowship Program. https://www.macfound.org/maps/1/

Gans, H. J. (2012). "Whitening" and the Changing American Racial Hierarchy. Du Bois Review, 9, 267-279. https://doi.org/10.1017/S1742058X12000288

Garber, M. (2002). Our Genius Problem. The Atlantic Monthly. theatlantic.com/magazine/archive/2002/12/our-genius-problem/308435/

Goldberg, S. (2017). Genius Takes Many Forms. National Geographic, 231, C5.

Hernandez, L. (2013). 11 in Region Win MacArthur Genius Grants. WNYC News. https://www.wnyc.org/story/macarthur-foundation-announces-2013-genius-fellows/

Isaacson, W. (2017). The Making of Genius. Time Magazine, 190, 60-67.

Jilani, S. (2020). My Daughter Passes for White: She belongs in a Way I Never Could. I'm Comforted and Worried (pp. 9). New York Times.

Kaba, A. J. (2012a). Analyzing the Anglo-American Hegemony in the Times Higher Education Rankings. Education Policy Analysis Archives, 20, 1-53. 
https://doi.org/10.14507/epaa.v20n21.2012

Kaba, A. J. (2012b). Talented Tenth: An Analysis of the 2011 Root Magazine's 100 Most Influential Young Black Americans. International Journal of Humanities and Social Science, 2, 1-31.

Kaba, A. J. (2013a). Profile of Contributors to the American Economic Review, 2010: Human Capital Theory, Gender and Race. Irvine, CA: Scientific Research Publishing, Inc. http://file.scirp.org/pdf/PCAER chapter 2014091914502967.pdf

Kaba, A. J. (2013b). Profile of Contributors to the American Political Science Review, 2010. Journal of Politics and Law, 6, 54-82. https://doi.org/10.5539/jpl.v6n2p54

Kaba, A. J. (2015). Contributors to the American Sociological Review, 2010. Sociology Mind, 5, 114-146. https://doi.org/10.4236/sm.2015.52012

Kaba, A. J. (2016). Conceptualizing Tolerance as Recognition: Black American Endowed and Distinguished Professors of Education in US Colleges and Universities. Sociology Mind, 6, 1-31. https://doi.org/10.4236/sm.2016.61001

Kaba, A. J. (2017a). America's 'Great Immigrants': An Analysis of Carnegie Corporation's Honorees, 2006-2015. London: Adonis \& Abbey Publishers Ltd.

Kaba, A. J. (2017b). Educational Attainment, Citizenship, and Black American Women in Elected and Appointed National Leadership Positions. The Review of Black Political Economy, 44, 99-136. https://doi.org/10.1007/s12114-017-9245-1

Kalb, C. (2017). Genius. National Geographic, 231, 30-55.

Kinsley, M. (1981). What's So Great about Excellence? Michael Kinsley on the MacArthur Grants. The New Republic. newrepublic.com/article/108017/whats-so-great-about-excellence

MacArthur Fellows Program: Summary of 2012-2013 Review (2013). MacArthur Foundation.

https://www.macfound.org/media/files/MacArthur Fellows Program Review final 1. pdf

MacArthur Fellows: The First 25, 1981-2005. (2005). The John D. and Catherine T. MacArthur Foundation. 140 South Dearborn Street. Chicago, Illinois (410 p). https://www.macfound.com

Miller, C. C., Quealy, K., \& Sanger-Katz, M. (2018). The Top Jobs Where Women are Outnumbered by Men Named John. New York Times.

https://www.nytimes.com/interactive/2018/04/24/upshot/women-and-men-named-joh n.html

Moritz, C. (1998). Exploring Cultural Geography. Syracuse University Magazine, 15, 28-29.

National University Rankings, 2020 (2019). U.S. News and World Report. https://www.usnews.com/best-colleges/rankings/national-universities

Orner, R. (2016). Genius. Salem Press Encyclopedia (5 p).

Pais, A. J. (2011). Genesis of a Genius (pp. 20-21). India Abroad. https://doi.org/10.12968/eqhe.2011.1.2.20

Patchett, A. (2017). Tribute to Primatologist Jane Goodall (pp. 64). Time Magazine.

Pick, G. (1995). The MacArthur Manner. Chicago Tribune. https://www.chicagotribune.com/news/ct-xpm-1995-12-03-9512030398-story.html

Powell, K. (2008). Best in Class. Nature, 455, 455-458. https://doi.org/10.1038/455455a

Review Affirms Impact and Inspiration of MacArthur Fellows Program (2013). MacAr- 
thur Fellowship Program.

https://www.macfound.org/press/evaluation/macarthur-fellows-program-review-sum mary/

Rocca, A. (2017). 'I Don't Feel Like a Genius': David Foster Wallace, Trickle-Down Aesthetics, and the MacArthur Foundation. Arizona Quarterly: A Journal of American Literature, Culture, and Theory, 73, 85-111. https://doi.org/10.1353/arq.2017.0003

Schimke, D. (2016). Pure Genius. Public Art Review, 298, 38-49.

Selected Population Profile in the United States: 2017 American Community Survey 1 Year-Estimates (2020). American Indian and Alaska Native. American Community Survey. United States Census Bureau.

https://data.census.gov/cedsci/table?d=ACS\%205-Year\%20Estimates\%20Data\%20Profi les\&table=DP05\&tid=ACSDP5Y2017.DP05

Silka, L. (2014). Encouraging Innovation: Thoughts from Ted Ames, Prize Winner. Maine Policy Review, 23, 82-85.

Simonton, D. K. (2017). Intellectual Genius in the Islamic Golden Age: Cross-Civilization Replications, Extensions, and Modifications. Psychology of Aesthetics, Creativity, and the Arts, 12, 125-135. https://doi.org/10.1037/aca0000110

Standards for the Classification of Federal Data on Race and Ethnicity (1995). Standards for the Classification of Federal Data on Race and Ethnicity. United States Federal Register. Executive Office of the President of the United States, Office of Management and Budget (OMB), Office of Information and Regulatory Affairs.

obamawhitehouse.archives.gov/omb/fedreg_race-ethnicity

Sternberg, R. J. (2006). The Nature of Creativity. Creativity Research Journal, 18, 87-98. https://doi.org/10.1207/s15326934cri1801 10

Table 1. Educational Attainment of the Population 18 Years and Over, by Age, Sex, Race, and Hispanic Origin: 2018 (2019). Table 1. Educational Attainment of the Population 18 Years and Over, by Age, Sex, Race, and Hispanic Origin: 2018. United States Census Bureau.

census.gov/data/tables/2018/demo/education-attainment/cps-detailed-tables.html

Von Gunten, C. F. (2009). Genius. Journal of Palliative Medicine, 12, 5. https://doi.org/10.1089/jpm.2009.9699

Wallerstein, M. B. (2002). Wither the Role of Private Foundations in Support of International Security Policy. Nonproliferation Review, 9, 83-91. https://doi.org/10.1080/10736700208436875

Ward, F. C. (2001). The Birth of the MacArthur Fellows Program. Foundation News and Commentary, 42, 38-40.

Wooster, M. M. (2010). The MacArthur Mistake. Commentary, 130, 39-44.

Wooster, M. M. (2014). Those Unassailable 'Genius Grants'. Philanthropy Daily. https://www.philanthropydaily.com/those-unassailable-genius-grants/

Yancey, G. (2003). Who Is White: Latinos, Asians, and the New Black/Nonblack Divide. Boulder, CO: Lynne Rienner Publishers.

Zuckerman, H. (1992). The Proliferation of Prizes: Nobel Complements and Nobel Surrogates in the Reward System of Science. Theoretical Medicine, 13, 217-231. https://doi.org/10.1007/BF02163629 


\section{Appendices}

Table A1. Alma Mater of Earned Highest/Terminal Higher Education Degree and type of Degree of MacArthur Fellows, 1981 to 2018, by Sex and Race [N = 232 institutions (174 institutions in the U.S. and 58 outside the U.S.)].

\begin{tabular}{|c|c|c|c|c|c|c|c|c|c|c|c|c|c|c|c|}
\hline Alma Mater & & $\%$ of & $\%$ of all & & & & & & & & & & & & \\
\hline Northeast & $\#$ & U.S. & Fellows & Men & $\%$ & Women & $\%$ & WM & WW & $\mathrm{BM}$ & BW & $\mathrm{AM}$ & AW & NAM & NAW \\
\hline \multicolumn{16}{|l|}{ Connecticut } \\
\hline University of Connecticut & 2 & 0.2 & 0.2 & 2 & 100 & & & 1 & & & & 1 & & & \\
\hline Wesleyan University & 3 & 0.3 & 0.3 & 3 & 100 & & & 2 & & & & 1 & & & \\
\hline Yale University & 61 & 7.1 & 6.3 & 34 & 55.7 & 27 & 44.3 & 27 & 17 & 5 & 8 & 2 & 2 & & \\
\hline Total & 66 & 7.6 & 6.8 & 39 & & 27 & & 30 & 17 & 5 & 8 & 4 & 2 & & \\
\hline \multicolumn{16}{|l|}{ Maine } \\
\hline Bates College & 1 & 0.1 & 0.1 & 1 & 100 & & & & & 1 & & & & & \\
\hline University of Maine & 1 & 0.1 & 0.1 & 1 & 100 & & & 1 & & & & & & & \\
\hline Total & 2 & 0.2 & 0.2 & 2 & & & & 1 & & 1 & & & & & \\
\hline \multicolumn{16}{|l|}{ Massachusetts } \\
\hline Amherst College & 1 & 0.1 & 0.1 & & & 1 & 100 & & 1 & & & & & & \\
\hline Boston College & 1 & 0.1 & 0.1 & & & 1 & 100 & & 1 & & & & & & \\
\hline Boston University & 1 & 0.1 & 0.1 & & & 1 & 100 & & & & 1 & & & & \\
\hline Brandeis University & 4 & 0.5 & 0.4 & 3 & 75 & 1 & 25 & 2 & 1 & 1 & & & & & \\
\hline Clark University & 1 & 0.1 & 0.1 & 1 & 100 & & & 1 & & & & & & & \\
\hline Hampshire College & 1 & 0.1 & 0.1 & 1 & 100 & & & 1 & & & & & & & \\
\hline Harvard University & 119 & 13.8 & 12.3 & 79 & 66.4 & 40 & 33.6 & 65 & 29 & 5 & 9 & 8 & 2 & 1 & \\
\hline Lesley University & 1 & 0.1 & 0.1 & & & 1 & 100 & & 1 & & & & & & \\
\hline $\begin{array}{c}\text { Massachusetts Institute of } \\
\text { Technology }\end{array}$ & 32 & 3.7 & 3.3 & 19 & 59.4 & 13 & 40.6 & 17 & 10 & 1 & & 1 & 2 & & 1 \\
\hline Mount Holyoke College & 1 & 0.1 & 0.1 & & & 1 & 100 & & & & 1 & & & & \\
\hline $\begin{array}{c}\text { New England } \\
\text { Conservatory of Music }\end{array}$ & 1 & 0.1 & 0.1 & 1 & 100 & & & & & 1 & & & & & \\
\hline Northeastern University & 2 & 0.2 & 0.2 & & & 2 & 100 & & 2 & & & & & & \\
\hline Radcliffe College & 4 & 0.5 & 0.4 & & & 4 & 100 & & 3 & & 1 & & & & \\
\hline Smith College & 1 & 0.1 & 0.1 & & & 1 & 100 & & 1 & & & & & & \\
\hline Tufts University & 1 & 0.1 & 0.1 & 1 & 100 & & & 1 & & & & & & & \\
\hline $\begin{array}{c}\text { University of } \\
\text { Massachusetts, Amherst. }\end{array}$ & 4 & 0.5 & 0.4 & 1 & 25 & 3 & 75 & & 3 & & & & & 1 & \\
\hline Williams College & 1 & 0.1 & 0.1 & 1 & 100 & & & 1 & & & & & & & \\
\hline Total & 176 & 20.3 & 18.2 & 107 & & 69 & & 88 & 52 & 8 & 12 & 9 & 4 & 2 & 1 \\
\hline Dartmouth College & 2 & 0.2 & 0.2 & 1 & 50 & 1 & 50 & 1 & 1 & & & & & & \\
\hline $\begin{array}{c}\text { University of New } \\
\text { Hampshire }\end{array}$ & 2 & 0.2 & 0.2 & & & 2 & 100 & & 1 & & 1 & & & & \\
\hline Total & 4 & 0.5 & 0.4 & 1 & & 3 & & 1 & 2 & & 1 & & & & \\
\hline
\end{tabular}




\section{Continued}

\begin{tabular}{|c|c|c|c|c|c|c|c|c|c|c|c|c|c|}
\hline New Jersey & & & & & & & & & & & & & \\
\hline Drew University & 1 & 0.1 & 0.1 & 1 & 100 & & & & & 1 & & & \\
\hline Princeton University & 41 & 4.7 & 4.2 & 27 & 65.9 & 14 & 34.1 & 24 & 14 & & & 3 & \\
\hline $\begin{array}{c}\text { Rutgers University, New } \\
\text { Brunswick }\end{array}$ & 5 & 0.6 & 0.5 & 4 & 80 & 1 & 20 & 3 & 1 & 1 & & & \\
\hline $\begin{array}{l}\text { University of Medicine \& } \\
\text { Dentistry of New Jersey }\end{array}$ & 1 & 0.1 & 0.1 & 1 & 100 & & & 1 & & & & & \\
\hline Total & 48 & 5.5 & 5.0 & 33 & & 15 & & 28 & 15 & 2 & & 3 & \\
\hline New York & & & & & & & & & & & & & \\
\hline Albany Medical College & 1 & 0.1 & 0.1 & & & 1 & 100 & & 1 & & & & \\
\hline $\begin{array}{c}\text { Bank Street College of } \\
\text { Education }\end{array}$ & 1 & 0.1 & 0.1 & & & 1 & 100 & & 1 & & & & \\
\hline Bard College & 1 & 0.1 & 0.1 & 1 & 100 & & & 1 & & & & & \\
\hline City Unity of New York & 12 & 1.4 & 1.2 & 4 & 33.3 & 8 & 66.7 & 3 & 7 & 1 & 1 & & \\
\hline Columbia University & 44 & 5.1 & 4.6 & 26 & 59.1 & 18 & 40.9 & 22 & 16 & 3 & 1 & 1 & 1 \\
\hline $\begin{array}{c}\text { Cooper Union School of } \\
\text { Art }\end{array}$ & 2 & 0.2 & 0.2 & 1 & 50 & 1 & 50 & & 1 & 1 & & & \\
\hline Cornell University & 20 & 2.3 & 2.1 & 12 & 60 & 8 & 40 & 11 & 8 & 1 & & & \\
\hline Fordham University & 1 & 0.1 & 0.1 & 1 & 100 & & 0 & 1 & & & & & \\
\hline Hofstra University & 1 & 0.1 & 0.1 & & & 1 & 100 & & 1 & & & & \\
\hline Juilliard School & 4 & 0.5 & 0.4 & 2 & 50 & 2 & 50 & 2 & 2 & & & & \\
\hline Long Island University & 1 & 0.1 & 0.1 & 1 & 100 & & & 1 & & & & & \\
\hline Manhattan College & 1 & 0.1 & 0.1 & 1 & 100 & & & 1 & & & & & \\
\hline Manhattan School of Music & 3 & 0.3 & 0.3 & 2 & 66.7 & 1 & 33.3 & 1 & 1 & 1 & & & \\
\hline Mount St. Mary College & 1 & 0.1 & 0.1 & & & 1 & 100 & & 1 & & & & \\
\hline New School & 2 & 0.2 & 0.2 & & & 2 & 100 & & 2 & & & & \\
\hline New York Law School & 1 & 0.1 & 0.1 & 1 & 100 & & & 1 & & & & & \\
\hline New York University & 19 & 2.2 & 2.0 & 12 & 63.2 & 7 & 36.8 & 9 & 5 & 3 & 1 & & 1 \\
\hline Rockefeller University & 3 & 0.3 & 0.3 & 2 & 66.7 & 1 & 33.3 & 2 & 1 & & & & \\
\hline Sarah Lawrence College & 1 & 0.1 & 0.1 & & & 1 & 100 & & 1 & & & & \\
\hline School of Visual Arts & 2 & 0.2 & 0.2 & & & 2 & 100 & & 2 & & & & \\
\hline Siena College & 1 & 0.1 & 0.1 & 1 & 100 & & & 1 & & & & & \\
\hline Skidmore College & 1 & 0.1 & 0.1 & & & 1 & 100 & & 1 & & & & \\
\hline $\begin{array}{l}\text { State University of New } \\
\text { York, College of } \\
\text { Environmental \& Forestry }\end{array}$ & 1 & 0.1 & 0.1 & 1 & 100 & & & 1 & & & & & \\
\hline $\begin{array}{l}\text { State University of New } \\
\text { York, Brockport }\end{array}$ & 1 & 0.1 & 0.1 & & & 1 & 100 & & 1 & & & & \\
\hline $\begin{array}{c}\text { State University of New } \\
\text { York, Buffalo }\end{array}$ & 3 & 0.3 & 0.3 & & & 3 & 100 & & 2 & & & & 1 \\
\hline
\end{tabular}




\section{Continued}

\begin{tabular}{|c|c|c|c|c|c|c|c|c|c|c|c|c|c|c|c|}
\hline $\begin{array}{c}\text { State University of New } \\
\text { York, Purchase }\end{array}$ & 1 & 0.1 & 0.1 & 1 & 100 & & & & & 1 & & & & & \\
\hline $\begin{array}{l}\text { State University of New } \\
\text { York, Stony Brook }\end{array}$ & 1 & 0.1 & 0.1 & 1 & 100 & & & & & 1 & & & & & \\
\hline Syracuse University & 4 & 0.5 & 0.4 & 2 & 50 & 2 & 50 & 2 & 1 & & 1 & & & & \\
\hline Union College & 1 & 0.1 & 0.1 & & & 1 & 100 & & 1 & & & & & & \\
\hline $\begin{array}{l}\text { Union Theological } \\
\text { Seminary }\end{array}$ & 1 & 0.1 & 0.1 & 1 & 100 & & & 1 & & & & & & & \\
\hline University of Rochester & 2 & 0.2 & 0.2 & 2 & 100 & & & 2 & & & & & & & \\
\hline Yeshiva University & 1 & 0.1 & 0.1 & 1 & 100 & & & 1 & & & & & & & \\
\hline Total & 139 & 16.1 & 14.4 & 76 & & 63 & & 63 & 56 & 12 & 4 & 1 & 3 & & \\
\hline \multicolumn{16}{|l|}{ Pennsylvania } \\
\hline Bryn Mawr College & 1 & 0.1 & 0.1 & & & 1 & 100 & & 1 & & & & & & \\
\hline $\begin{array}{l}\text { Carnegie Mellon } \\
\text { University }\end{array}$ & 2 & 0.2 & 0.2 & 2 & 100 & & & 2 & & & & & & & \\
\hline Curtis Institute of Music & 1 & 0.1 & 0.1 & & & 1 & 100 & & 1 & & & & & & \\
\hline $\begin{array}{l}\text { Pennsylvania State } \\
\text { University }\end{array}$ & 2 & 0.2 & 0.2 & 2 & 100 & & & 1 & & 1 & & & & & \\
\hline Temple University & 2 & 0.2 & 0.2 & 2 & 100 & & & 2 & & & & & & & \\
\hline $\begin{array}{l}\text { University of } \\
\text { Pennsylvania }\end{array}$ & 12 & 1.4 & 1.2 & 8 & 66.7 & 4 & 33.3 & 6 & 3 & 2 & & & 1 & & \\
\hline University of Pittsburgh & 3 & 0.3 & 0.3 & 2 & 66.7 & 1 & 33.3 & & 1 & 2 & & & & & \\
\hline Total & 23 & 2.7 & 2.4 & 16 & & 7 & & 11 & 6 & 5 & & & 1 & & \\
\hline \multicolumn{16}{|l|}{ Rhode Island } \\
\hline Brown University & 7 & 0.8 & 0.7 & 3 & 42.9 & 4 & 57.1 & 3 & 3 & & 1 & & & & \\
\hline $\begin{array}{c}\text { Rhode Island School of } \\
\text { Design }\end{array}$ & 9 & 1.0 & 0.9 & 3 & 33.3 & 6 & 66.7 & 3 & 4 & & 1 & & 1 & & \\
\hline Total & 16 & 1.8 & 1.7 & 6 & & 10 & & 6 & 7 & & 2 & & 1 & & \\
\hline \multicolumn{16}{|l|}{ Vermont } \\
\hline Goddard College & 1 & 0.1 & 0.1 & & & 1 & 100 & & 1 & & & & & & \\
\hline Total & 475 & 54.9 & 49.2 & 280 & 58.9 & 195 & 41.1 & 228 & 156 & 33 & 27 & 17 & 11 & 2 & 1 \\
\hline$\%$ of U.S. & & & & 32.4 & & 22.5 & & 26.4 & 18.0 & 3.8 & 3.1 & 2.0 & 1.3 & 0.2 & 0.1 \\
\hline$\%$ of all Fellows & & & & 29.0 & & 20.2 & & 23.63 & 16.17 & 3.42 & 2.8 & 1.762 & 1.14 & 0.21 & 0.1 \\
\hline \multicolumn{16}{|l|}{ Midwest } \\
\hline \multicolumn{16}{|l|}{ Illinois } \\
\hline $\begin{array}{l}\text { Loyola University } \\
\text { Chicago }\end{array}$ & 1 & 0.1 & 0.1 & 1 & 100 & & 0 & 1 & & & & & & & \\
\hline Northwestern University & 5 & 0.6 & 0.5 & 2 & 40 & 3 & 60 & 2 & 3 & & & & & & \\
\hline $\begin{array}{l}\text { School of the Art Institute } \\
\text { of Chicago }\end{array}$ & 1 & 0.1 & 0.1 & 1 & 100 & & 0 & 1 & & & & & & & \\
\hline
\end{tabular}




\section{Continued}

\begin{tabular}{|c|c|c|c|c|c|c|c|c|c|c|c|c|c|}
\hline University of Chicago & 24 & 2.8 & 2.5 & 18 & 75 & 6 & 25 & 15 & 5 & 1 & 1 & 1 & 1 \\
\hline $\begin{array}{l}\text { University of Illinois, } \\
\text { Urbana-Champaign }\end{array}$ & 9 & 1.0 & 0.9 & 9 & 100 & & 0 & 7 & & 2 & & & \\
\hline $\begin{array}{l}\text { University of Illinois at } \\
\text { Chicago Circle }\end{array}$ & 1 & 0.1 & 0.1 & & 0 & 1 & 100 & & 1 & & & & \\
\hline Total & 41 & 4.7 & 4.2 & 31 & & 10 & & 26 & 9 & 3 & 1 & 1 & 1 \\
\hline \multicolumn{14}{|l|}{ Indiana } \\
\hline Indiana University & 7 & 0.8 & 0.7 & 6 & 85.7 & 1 & 14.3 & 5 & 1 & & 1 & & \\
\hline Purdue University & 3 & 0.3 & 0.3 & 2 & 66.7 & 1 & 33.3 & & 1 & & 2 & & \\
\hline Total & 10 & 1.2 & 1.0 & 8 & & 2 & & 5 & 2 & & 3 & & \\
\hline \multicolumn{14}{|l|}{ Iowa } \\
\hline University of Iowa & 12 & 1.4 & 1.2 & 5 & 41.7 & 7 & 58.3 & 5 & 5 & & & 2 & \\
\hline Grinnell College & 1 & 0.1 & 0.1 & & 0 & 1 & 100 & & 1 & & & & \\
\hline Total & 13 & 1.5 & 1.3 & 5 & & 8 & & 5 & 6 & & & 2 & \\
\hline \multicolumn{14}{|l|}{ Kansas } \\
\hline University of Kansas & 5 & 0.6 & 0.5 & 3 & 60 & 2 & 40 & 3 & 2 & & & & \\
\hline
\end{tabular}

Michigan

$\begin{array}{lllllllll}\text { Kalamazoo College } & 1 & 0.1 & 0.1 & 1 & 100 & 0 & 1\end{array}$

$\begin{array}{llllllll}\text { Michigan State University } & 1 & 0.1 & 0.1 & 1 & 100 & 0 & 1\end{array}$

$\begin{array}{llllllll}\text { Oakland University } & 1 & 0.1 & 0.1 & 0 & 1 & 100 & 1\end{array}$

$\begin{array}{lllllllllllll}\text { University of Michigan } & 14 & 1.6 & 1.5 & 7 & 50 & 7 & 50 & 6 & 4 & 1 & 3\end{array}$

$\begin{array}{cccccccc}\text { Western Michigan } & 1 & 0.1 & 0.1 & 0 & 1 & 100 & 1 \\ \text { University } & & & \end{array}$

$\begin{array}{lllllllllll}\text { Total } & 18 & 2.1 & 1.9 & 9 & 9 & 7 & 5 & 2 & 4\end{array}$

Minnesota

$\begin{array}{llllllllllll}\text { University of Minnesota } & 4 & 0.5 & 0.4 & 1 & 25 & 3 & 75 & 1 & 2 & \end{array}$

Ohio

$\begin{array}{llllllllll}\text { Antioch College } & 2 & 0.2 & 0.2 & 1 & 50 & 1 & 50 & 1 & 1\end{array}$

$\begin{array}{cccccccc}\begin{array}{c}\text { Case Western Reserve } \\ \text { University }\end{array} & 2 & 0.2 & 0.2 & 2 & 100 & 0 & 2\end{array}$

$\begin{array}{llllllllll}\text { Oberlin College } & 4 & 0.5 & 0.4 & 2 & 50 & 2 & 50 & 2 & 2\end{array}$

$\begin{array}{lllllllll}\text { Oberlin Conservatory } & 2 & 0.2 & 0.2 & 0 & 2 & 100 & 1 & 1\end{array}$

$\begin{array}{llllllll}\text { Ohio State University } & 1 & 0.1 & 0.1 & 1 & 100 & 0 & 1\end{array}$

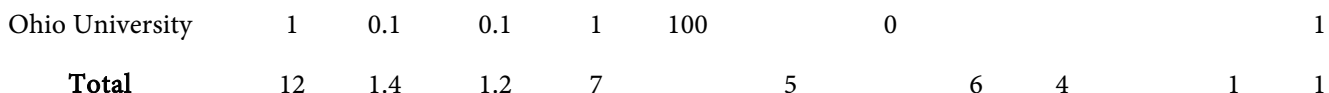

Total

Wisconsin

Milwaukee School of Engineering 


\section{Continued}

\begin{tabular}{|c|c|c|c|c|c|c|c|c|c|c|c|c|c|c|}
\hline $\begin{array}{l}\text { University of Wisconsin, } \\
\text { Madison }\end{array}$ & 11 & 1.3 & 1.1 & 5 & 45.5 & 6 & 54.5 & 5 & 6 & & & & & \\
\hline Total & 12 & 1.4 & 1.2 & 6 & & 6 & & 6 & 6 & & & & & \\
\hline Total & 115 & 13.3 & 11.9 & 70 & 60.87 & 45 & 39.13 & 59 & 36 & 5 & 6 & 5 & 3 & 1 \\
\hline \% of U.S. & & & & 8.1 & & 5.2 & & 6.821 & 4.162 & 0.58 & 0.69 & 0.578 & 0.35 & 0.12 \\
\hline$\%$ of all Fellows & & & & 7.3 & & 4.7 & & 6.1 & 3.7 & 0.52 & 0.62 & 0.52 & 0.31 & 0.10 \\
\hline \multicolumn{15}{|l|}{ South } \\
\hline \multicolumn{15}{|l|}{ Alabama } \\
\hline Auburn University & 2 & 0.231 & 0.21 & 1 & 50 & 1 & 50 & 1 & & & 1 & & & \\
\hline Samford University & 1 & 0.116 & 0.10 & & 0 & 1 & 100 & & & & 1 & & & \\
\hline $\begin{array}{c}\text { University of Alabama, } \\
\text { Birmingham }\end{array}$ & 1 & 0.116 & 0.10 & & 0 & 1 & 100 & & & & 1 & & & \\
\hline Total & 4 & 0.46 & 0.41 & 1 & & 3 & & 1 & & & 3 & & & \\
\hline \multicolumn{15}{|l|}{ Arkansas } \\
\hline Philander Smith College & 1 & 0.116 & 0.10 & 1 & 100 & & 0 & & & 1 & & & & \\
\hline University of Arkansas & 1 & 0.116 & 0.10 & & 0 & 1 & 100 & & 1 & & & & & \\
\hline Total & 2 & 0.23 & 0.21 & 1 & & 1 & & & 1 & 1 & & & & \\
\hline \multicolumn{15}{|l|}{ Florida } \\
\hline $\begin{array}{l}\text { Florida International } \\
\text { Seminary }\end{array}$ & 1 & 0.116 & 0.10 & 1 & 100 & & 0 & 1 & & & & & & \\
\hline University of Florida & 4 & 0.462 & 0.41 & 1 & 25 & 3 & 75 & 1 & 2 & & 1 & & & \\
\hline University of Miami & 1 & 0.116 & 0.10 & 1 & 100 & & 0 & & & 1 & & & & \\
\hline Total & 6 & 0.69 & 0.62 & 3 & & 3 & & 2 & 2 & 1 & 1 & & & \\
\hline \multicolumn{15}{|l|}{ Georgia } \\
\hline Emory University & 1 & 0.116 & 0.10 & & 0 & 1 & 100 & & 1 & & & & & \\
\hline $\begin{array}{l}\text { Georgia Institute of } \\
\text { Technology }\end{array}$ & 1 & 0.116 & 0.10 & 1 & 100 & & 0 & & & & & 1 & & \\
\hline University of Georgia & 2 & 0.231 & 0.21 & 2 & 100 & & 0 & 2 & & & & & & \\
\hline Total & 4 & 0.46 & 0.41 & 3 & & 1 & & 2 & 1 & & & 1 & & \\
\hline \multicolumn{15}{|l|}{ Louisiana } \\
\hline Tulane University & 1 & 0.116 & 0.10 & 1 & 100 & & 0 & 1 & & & & & & \\
\hline $\begin{array}{l}\text { University of Louisiana at } \\
\text { Lafayette }\end{array}$ & 1 & 0.116 & 0.10 & & 0 & 1 & 100 & & 1 & & & & & \\
\hline $\begin{array}{c}\text { University of } \\
\text { Southwestern Louisiana }\end{array}$ & 1 & 0.116 & 0.10 & & 0 & 1 & 100 & & 1 & & & & & \\
\hline Total & 3 & 0.35 & 0.31 & 1 & & 2 & & 1 & 2 & & & & & \\
\hline \multicolumn{15}{|l|}{ Maryland } \\
\hline Johns Hopkins University & 16 & 1.85 & 1.66 & 9 & 56.25 & 7 & 43.75 & 8 & 5 & 1 & 2 & & & \\
\hline $\begin{array}{l}\text { Maryland Institute } \\
\text { College of Art }\end{array}$ & 1 & 0.116 & 0.10 & & 0 & 1 & 100 & & 1 & & & & & \\
\hline
\end{tabular}




\section{Continued}

\begin{tabular}{|c|c|c|c|c|c|c|c|c|c|c|c|c|}
\hline $\begin{array}{l}\text { University of Maryland, } \\
\text { College Park }\end{array}$ & 7 & 0.809 & 0.73 & 2 & 28.6 & 5 & 71.4 & 2 & 5 & & & \\
\hline Total & 24 & 2.77 & 2.49 & 11 & & 13 & & 10 & 11 & 1 & 2 & \\
\hline \multicolumn{13}{|l|}{ North Carolina } \\
\hline Duke University & 6 & 0.694 & 0.62 & 3 & 50 & 3 & 50 & 2 & 3 & 1 & & \\
\hline $\begin{array}{c}\text { North Carolina State } \\
\text { University }\end{array}$ & 1 & 0.116 & 0.10 & 1 & 100 & & 0 & 1 & & & & \\
\hline $\begin{array}{l}\text { University of North } \\
\text { Carolina, Chapel Hill }\end{array}$ & 4 & 0.462 & 0.41 & 1 & 25 & 3 & 75 & 1 & 1 & & 2 & \\
\hline $\begin{array}{l}\text { University of North } \\
\text { Carolina at Greensboro }\end{array}$ & 1 & 0.116 & 0.10 & & 0 & 1 & 100 & & 1 & & & \\
\hline Wake Forest College & 1 & 0.116 & 0.10 & 1 & 100 & & 0 & 1 & & & & \\
\hline Total & 13 & 1.5 & 1.35 & 6 & & 7 & & 5 & 5 & 1 & 2 & \\
\hline \multicolumn{13}{|l|}{ Oklahoma } \\
\hline University of Tulsa & 1 & 0.116 & 0.10 & 1 & 100 & & 0 & 1 & & & & \\
\hline \multicolumn{13}{|l|}{ Tennessee } \\
\hline Meharry Medical College & 1 & 0.116 & 0.10 & 1 & 100 & & 0 & & & 1 & & \\
\hline University of Tennessee & 1 & 0.116 & 0.10 & 1 & 100 & & 0 & 1 & & & & \\
\hline Vanderbilt University & 2 & 0.231 & 0.21 & 1 & 50 & 1 & 50 & 1 & 1 & & & \\
\hline Total & 4 & 0.462 & 0.41 & 3 & & 1 & & 2 & 1 & 1 & & \\
\hline \multicolumn{13}{|l|}{ Texas } \\
\hline Texas A \& M University & 1 & 0.116 & 0.10 & 1 & 100 & & 0 & 1 & & & & \\
\hline University of Houston & 1 & 0.116 & 0.10 & 1 & 100 & & 0 & 1 & & & & \\
\hline $\begin{array}{c}\text { University of Texas at } \\
\text { Austin }\end{array}$ & 8 & 0.925 & 0.83 & 6 & 75 & 2 & 25 & 6 & 2 & & & \\
\hline Total & 10 & 1.16 & 1.04 & 8 & & 2 & & 8 & 2 & & & \\
\hline \multicolumn{13}{|l|}{ Virginia } \\
\hline George Mason University & 1 & 0.116 & 0.10 & & 0 & 1 & 100 & & & & 1 & \\
\hline Old Dominion University & 1 & 0.116 & 0.10 & & 0 & 1 & 100 & & & & & 1 \\
\hline University of Virginia & 5 & 0.578 & 0.52 & 3 & 60 & 2 & 40 & 2 & 2 & 1 & & \\
\hline $\begin{array}{c}\text { Virginia Commonwealth } \\
\text { University }\end{array}$ & 2 & 0.231 & 0.21 & & 0 & 2 & 100 & & 2 & & & \\
\hline Total & 9 & 1.04 & 0.93 & 3 & & 6 & & 2 & 4 & 1 & 1 & 1 \\
\hline \multicolumn{13}{|l|}{ Washington, D.C. } \\
\hline American University & 2 & 0.231 & 0.21 & 2 & 100 & & 0 & 2 & & & & \\
\hline Catholic University & 1 & 0.116 & 0.10 & 1 & 100 & & 0 & 1 & & & & \\
\hline Georgetown University & 1 & 0.116 & 0.10 & & 0 & 1 & 100 & & 1 & & & \\
\hline $\begin{array}{l}\text { George Washington } \\
\text { University }\end{array}$ & 2 & 0.231 & 0.21 & 1 & 50 & 1 & 50 & 1 & 1 & & & \\
\hline Howard University & 1 & 0.116 & 0.10 & & 0 & 1 & 100 & & & & 1 & \\
\hline
\end{tabular}




\section{Continued}

\begin{tabular}{|c|c|c|c|c|c|c|c|c|c|c|c|c|c|c|}
\hline Total & 7 & 0.81 & 0.73 & 4 & & 3 & & 4 & 2 & & 1 & & & \\
\hline \multicolumn{15}{|l|}{ West Virginia } \\
\hline West Virginia University & 1 & 0.116 & 0.10 & 1 & 100 & & 0 & 1 & & & & & & \\
\hline Total & 88 & 10.17 & 9.12 & 46 & 52.273 & 42 & 47.73 & 39 & 31 & 6 & 10 & 1 & & 1 \\
\hline \% of U.S. & & & & 5.318 & & 4.86 & & 4.5 & 3.6 & 0.69 & 1.16 & 0.12 & & 0.12 \\
\hline$\%$ of all Fellows & & & & 4.767 & & 4.4 & & 4.0 & 3.2 & 0.62 & 1.04 & 0.104 & & 0.10 \\
\hline \multicolumn{15}{|l|}{ West } \\
\hline \multicolumn{15}{|l|}{ Alaska } \\
\hline Alaska Pacific University & 1 & 0.116 & 0.10 & & 0 & 1 & 100 & & & & & & & 1 \\
\hline \multicolumn{15}{|l|}{ Arizona } \\
\hline Arizona State University & 1 & 0.116 & 0.10 & 1 & 100 & & 0 & 1 & & & & & & \\
\hline University of Arizona & 3 & 0.347 & 0.31 & 2 & 66.7 & 1 & 33.3 & 2 & & & & & & 1 \\
\hline Total & 4 & 0.46 & 0.41 & 3 & & 1 & & 3 & & & & & & 1 \\
\hline \multicolumn{15}{|l|}{ California } \\
\hline $\begin{array}{c}\text { American Conservatory } \\
\text { Theater }\end{array}$ & 1 & 0.116 & 0.10 & & 0 & 1 & 100 & & & & 1 & & & \\
\hline $\begin{array}{l}\text { Art Center College of } \\
\text { Design }\end{array}$ & 1 & 0.116 & 0.10 & 1 & 100 & & 0 & 1 & & & & & & \\
\hline $\begin{array}{c}\text { California Institute of the } \\
\text { Arts }\end{array}$ & 2 & 0.231 & 0.21 & 2 & 100 & & 0 & 1 & & 1 & & & & \\
\hline $\begin{array}{c}\text { California Institute of } \\
\text { Technology }\end{array}$ & 20 & 2.312 & 2.07 & 16 & 80 & 4 & 20 & 14 & 4 & 1 & & 1 & & \\
\hline $\begin{array}{l}\text { California State } \\
\text { University at East Bay }\end{array}$ & 1 & 0.116 & 0.10 & 1 & 100 & & 0 & & & & & 1 & & \\
\hline $\begin{array}{c}\text { Claremont Graduate } \\
\text { School }\end{array}$ & 3 & 0.347 & 0.31 & 1 & 33.3 & 2 & 66.7 & 1 & 2 & & & & & \\
\hline Mills College & 3 & 0.347 & 0.31 & & 0 & 3 & 100 & & 2 & & 1 & & & \\
\hline Otis Art Institute & 1 & 0.116 & 0.10 & 1 & 100 & & 0 & & & 1 & & & & \\
\hline Pasadena City College & 1 & 0.116 & 0.10 & & 0 & 1 & 100 & & & & 1 & & & \\
\hline Pepperdine University & 1 & 0.116 & 0.10 & 1 & 100 & & 0 & & & 1 & & & & \\
\hline $\begin{array}{c}\text { San Francisco State } \\
\text { College }\end{array}$ & 1 & 0.116 & 0.10 & 1 & 100 & & 0 & & & 1 & & & & \\
\hline Scripps Research Institute & 1 & 0.116 & 0.10 & 1 & 100 & & 0 & 1 & & & & & & \\
\hline Sonoma State University & 1 & 0.116 & 0.10 & 1 & 100 & & 0 & 1 & & & & & & \\
\hline Stanford University & 20 & 2.312 & 2.07 & 16 & 80 & 4 & 20 & 14 & 2 & & & 2 & 2 & \\
\hline $\begin{array}{c}\text { University of California, } \\
\text { Berkeley }\end{array}$ & 51 & 5.896 & 5.28 & 36 & 70.6 & 15 & 29.4 & 31 & 13 & 1 & & 4 & 2 & \\
\hline $\begin{array}{l}\text { University of California, } \\
\text { Los Angeles }\end{array}$ & 17 & 1.965 & 1.76 & 9 & 52.9 & 8 & 47.1 & 6 & 7 & 1 & & 2 & & 1 \\
\hline $\begin{array}{c}\text { University of California, } \\
\text { San Diego }\end{array}$ & 6 & 0.694 & 0.62 & 3 & 50 & 3 & 50 & 3 & 2 & & 1 & & & \\
\hline
\end{tabular}




\section{Continued}

\begin{tabular}{|c|c|c|c|c|c|c|c|c|c|c|c|c|c|c|c|}
\hline $\begin{array}{l}\text { University of California, } \\
\text { San Francisco }\end{array}$ & 10 & 1.156 & 1.04 & 6 & 60 & 4 & 40 & 4 & 4 & 2 & & & & & \\
\hline $\begin{array}{l}\text { University of California, } \\
\text { Santa Barbara }\end{array}$ & 6 & 0.694 & 0.62 & 2 & 33.3 & 4 & 66.7 & 2 & 4 & & & & & & \\
\hline $\begin{array}{l}\text { University of California, } \\
\text { Santa Cruz }\end{array}$ & 2 & 0.231 & 0.21 & 2 & 100 & & 0 & 2 & & & & & & & \\
\hline $\begin{array}{l}\text { University of Southern } \\
\text { California }\end{array}$ & 4 & 0.462 & 0.41 & 2 & 50 & 2 & 50 & 2 & 1 & & & & 1 & & \\
\hline Wright Institute & 2 & 0.231 & 0.21 & 1 & 50 & 1 & 50 & & 1 & 1 & & & & & \\
\hline Total & 155 & 17.9 & 16.06 & 103 & & 52 & & 83 & 42 & 10 & 4 & 10 & 5 & & 1 \\
\hline \multicolumn{16}{|l|}{ Colorado } \\
\hline $\begin{array}{c}\text { University of Colorado at } \\
\text { Boulder }\end{array}$ & 1 & 0.116 & 0.10 & 1 & 100 & & 0 & 1 & & & & & & & \\
\hline University of Denver & 1 & 0.116 & 0.10 & & 0 & 1 & 100 & & 1 & & & & & & \\
\hline Total & 2 & 0.231 & 0.21 & 1 & & 1 & & 1 & 1 & & & & & & \\
\hline \multicolumn{16}{|l|}{ Hawaii } \\
\hline $\begin{array}{l}\text { University of Hawaii at } \\
\text { Mānoa }\end{array}$ & 1 & 0.116 & 0.10 & & 0 & 1 & 100 & & 1 & & & & & & \\
\hline \multicolumn{16}{|l|}{ Montana } \\
\hline $\begin{array}{l}\text { Great Falls Commercial } \\
\text { College }\end{array}$ & 1 & 0.116 & 0.10 & & 0 & 1 & 100 & & & & & & & & 1 \\
\hline Montana State University & 1 & 0.116 & 0.10 & & 0 & 1 & 100 & & & & & & & & 1 \\
\hline University of Montana & 1 & 0.116 & 0.10 & 1 & 100 & & 0 & & & & & & & 1 & \\
\hline Total & 3 & 0.35 & 0.31 & 1 & & 2 & & & & & & & & 1 & 2 \\
\hline \multicolumn{16}{|l|}{ New Mexico } \\
\hline $\begin{array}{l}\text { University of New } \\
\text { Mexico }\end{array}$ & 1 & 0.116 & 0.10 & & 0 & 1 & 100 & & & & & & & & 1 \\
\hline \multicolumn{16}{|l|}{ Oregon } \\
\hline $\begin{array}{l}\text { Oregon Health and } \\
\text { Science University }\end{array}$ & 1 & 0.116 & 0.10 & & 0 & 1 & 100 & & 1 & & & & & & \\
\hline Oregon State University & 1 & 0.116 & 0.10 & & 0 & 1 & 100 & & 1 & & & & & & \\
\hline Reed College & 1 & 0.1 & 0.1 & 1 & 100 & & 0 & 1 & & & & & & & \\
\hline University of Oregon & 1 & 0.116 & 0.10 & & 0 & 1 & 100 & & 1 & & & & & & \\
\hline Total & 4 & 0.462 & 0.41 & 1 & & 3 & & 1 & 3 & & & & & & \\
\hline \multicolumn{16}{|l|}{ Utah } \\
\hline University of Utah & 1 & 0.116 & 0.10 & 1 & 100 & & 0 & 1 & & & & & & & \\
\hline Utah State University & 1 & 0.116 & 0.10 & & 0 & 1 & 100 & & 1 & & & & & & \\
\hline Total & 2 & 0.23 & 0.21 & 1 & & 1 & & 1 & 1 & & & & & & \\
\hline \multicolumn{16}{|l|}{ Washington } \\
\hline $\begin{array}{l}\text { Washington State } \\
\text { University }\end{array}$ & 2 & 0.231 & 0.21 & 2 & 100 & & 0 & 1 & & 1 & & & & & \\
\hline
\end{tabular}




\section{Continued}

\begin{tabular}{|c|c|c|c|c|c|c|c|c|c|c|c|c|c|c|c|}
\hline University of Washington & 12 & 1.387 & 1.24 & 8 & 66.7 & 4 & 33.3 & 8 & 4 & & & & & & \\
\hline Total & 14 & 1.62 & 1.45 & 10 & & 4 & & 9 & 4 & 1 & & & & & \\
\hline Total & 187 & 21.62 & 19.38 & 120 & 64.2 & 67 & 35.8 & 98 & 52 & 11 & 4 & 10 & 5 & 1 & 6 \\
\hline \% of U.S. & & & & 13.9 & & 7.7 & & 11.33 & 6.01 & 1.27 & 0.46 & 1.16 & 0.58 & 0.12 & 0.69 \\
\hline$\%$ of all Fellows & & & & 12.4 & & 6.9 & & 10.16 & 5.4 & 1.14 & 0.41 & 1.04 & 0.52 & 0.1 & 0.62 \\
\hline United States Total & 865 & & 89.8 & 516 & 59.7 & 349 & 40.3 & 424 & 275 & 55 & 47 & 33 & 19 & 4 & 8 \\
\hline$\%$ of all Fellows & & & & 53.5 & & 36.2 & & 43.94 & 28.5 & 5.7 & 4.87 & 3.42 & 1.97 & 0.41 & 0.83 \\
\hline \multicolumn{16}{|l|}{ Canada } \\
\hline McGill University & 2 & & 0.21 & 1 & 50 & 1 & 50 & 1 & 1 & & & & & & \\
\hline $\begin{array}{c}\text { University of British } \\
\text { Columbia }\end{array}$ & 1 & & 0.10 & 1 & 100 & & 0 & 1 & & & & & & & \\
\hline University of Waterloo & 1 & & 0.10 & 1 & 100 & & 0 & 1 & & & & & & & \\
\hline University of Toronto & 1 & & 0.10 & & 0 & 1 & 100 & & 1 & & & & & & \\
\hline Total & 5 & & 0.52 & 3 & 60 & 2 & 40 & 3 & 2 & & & & & & \\
\hline$\%$ of all Fellows & & & & 0.311 & & 0.21 & & 0.31 & 0.21 & & & & & & \\
\hline Northern America & 870 & & 90.2 & 519 & 59.66 & 351 & 40.3 & 427 & 277 & 55 & 47 & 33 & 19 & 4 & 8 \\
\hline$\%$ of all Fellows & & & & 53.8 & & 36.4 & & 44.2 & 28.7 & 5.7 & 4.9 & 3.4 & 2.0 & 0.4 & 0.8 \\
\hline \multicolumn{16}{|l|}{ Africa } \\
\hline \multicolumn{16}{|l|}{ Western Africa } \\
\hline \multicolumn{16}{|l|}{ Nigeria } \\
\hline University of Ibadan & 1 & & 0.1 & & & 1 & 100 & & & & 1 & & & & \\
\hline \multicolumn{16}{|l|}{ Northern Africa } \\
\hline \multicolumn{16}{|l|}{ Egypt } \\
\hline Cairo University & 1 & & 0.1 & & & 1 & 100 & & 1 & & & & & & \\
\hline Africa Total & 2 & & 0.2 & & & 2 & 100 & & 1 & & 1 & & & & \\
\hline$\%$ of all Fellows & & & & & & 0.2 & & & 0.104 & & 0.1 & & & & \\
\hline \multicolumn{16}{|l|}{ Asia } \\
\hline \multicolumn{16}{|l|}{ Eastern Asia } \\
\hline \multicolumn{16}{|l|}{ China } \\
\hline $\begin{array}{l}\text { Central Academy of Fine } \\
\text { Art, Beijing }\end{array}$ & 1 & & 0.1 & 1 & 100 & & & & & & & 1 & & & \\
\hline $\begin{array}{c}\text { Chinese University of } \\
\text { Hong }\end{array}$ & 1 & & 0.1 & 1 & 100 & & & & & & & 1 & & & \\
\hline $\begin{array}{l}\text { University of Science and } \\
\text { Technology of China }\end{array}$ & 1 & & 0.1 & 1 & 100 & & & & & & & 1 & & & \\
\hline \multicolumn{16}{|l|}{ Japan } \\
\hline Kyoto University & 1 & & 0.1 & & 0 & 1 & 100 & & & & & & 1 & & \\
\hline Total & 4 & & 0.4 & 3 & 75 & 1 & 25 & & & & & 3 & 1 & & \\
\hline
\end{tabular}




\section{Continued}

Western Asia

Georgia

Tbilisi State University

$\begin{array}{lll}0.1 & 1 & 100\end{array}$

Israel

Weizmann Institute of Science

Technion - Israel Institute of Technology

$\begin{array}{ccccccccccc}0.1 & & 0 & 1 & 100 & & 1 & & & & \\ 0.3 & 2 & 66.667 & 1 & 33.33 & 2 & 1 & & & & \\ 0.7 & 5 & 71.429 & 2 & 28.57 & 2 & 1 & & & 3 & 1 \\ & 0.52 & & 0.21 & & 0.2 & 0.104 & 0 & 0 & 0.311 & 0.1\end{array}$

Europe

Eastern Europe

Hungary

Hungarian Academy of Sciences

$0.1 \quad 1 \quad 100$

1

Institute of Construction

$\begin{array}{lll}0.1 & 1 & 100\end{array}$

1

Poland

Institute of Social Sciences

$0.1-1$

1

National Theatrical Academy

$\begin{array}{lll}0.2 & 2 & 100\end{array}$

2

University of Warsaw 1

$\begin{array}{lll}0.1 & 1 & 100\end{array}$

1

Russia

L.D. Landau Institute of

$$
\text { Theo. Physics }
$$

Moscow State University 3

$0.1 \quad 1 \quad 100$

1

$\begin{array}{lll}0.3 & 3 & 100\end{array}$

3

Ukraine

Ukrainian Academy of Sciences

Total

11

1

$\%$ of all Fellows

$1.1 \quad 11 \quad 100$

11

Northern Europe

Denmark

University of Aarhus $\quad 1$

0.1

1

100

1

Ireland

Trinity College,

University of Dublin

$\begin{array}{lll}0.1 & 1 & 100\end{array}$

1

Sweden

Lund University $\quad 1$

0.1

$1 \quad 100$

1 


\section{Continued}

\begin{tabular}{|c|c|c|c|c|c|c|c|c|c|c|c|c|}
\hline \multicolumn{13}{|l|}{ United Kingdom } \\
\hline University of Cambridge & 15 & 1.6 & 11 & 73.3 & 4 & 26.7 & 8 & 2 & 1 & 1 & 2 & 1 \\
\hline $\begin{array}{l}\text { London School of } \\
\text { Economics }\end{array}$ & 2 & 0.2 & 2 & 100 & & & 1 & & 1 & & & \\
\hline University of Oxford & 18 & 1.9 & 14 & 77.8 & 4 & 22.2 & 12 & 4 & 1 & & 1 & \\
\hline University of London & 5 & 0.5 & 3 & 60 & 2 & 40 & 3 & 2 & & & & \\
\hline $\begin{array}{l}\text { University College, } \\
\text { London }\end{array}$ & 2 & 0.2 & 1 & 50 & 1 & 50 & 1 & 1 & & & & \\
\hline University of Manchester & 1 & 0.1 & 1 & 100 & & & 1 & & & & & \\
\hline $\begin{array}{l}\text { University of the Arts } \\
\text { London }\end{array}$ & 1 & 0.1 & 1 & 100 & & & 1 & & & & & \\
\hline University of East Anglia & 1 & 0.1 & 1 & 100 & & & 1 & & & & & \\
\hline Total & 45 & 4.7 & 34 & & 11 & & 28 & 9 & 3 & 1 & 3 & 1 \\
\hline Total & 48 & 5.0 & 35 & 72.9 & 13 & 27.1 & 29 & 11 & 3 & 1 & 3 & 1 \\
\hline$\%$ of all Fellows & & & 3.6 & & 1.3 & & 3.0 & 1.1 & 0.3 & 0.1 & 0.3 & 0.1 \\
\hline \multicolumn{13}{|l|}{ Southern Europe } \\
\hline \multicolumn{13}{|l|}{ Italy } \\
\hline University of Pisa & 1 & 0.1 & 1 & 100 & & & 1 & & & & & \\
\hline \multicolumn{13}{|l|}{ Western Europe } \\
\hline \multicolumn{13}{|l|}{ Austria } \\
\hline University of Vienna & 1 & 0.1 & 1 & 100 & & & 1 & & & & & \\
\hline $\begin{array}{c}\text { Technical University of } \\
\text { Vienna }\end{array}$ & 1 & 0.1 & & & 1 & 100 & & 1 & & & & \\
\hline \multicolumn{13}{|l|}{ Belgium } \\
\hline Free University & 1 & 0.1 & & & 1 & 100 & & 1 & & & & \\
\hline \multicolumn{13}{|l|}{ France } \\
\hline \multicolumn{13}{|l|}{ École Nationale } \\
\hline $\begin{array}{c}\text { Supérieure des Arts de la } \\
\text { Marionnette }\end{array}$ & 1 & 0.1 & 1 & 100 & & & 1 & & & & & \\
\hline $\begin{array}{l}\text { École Normale } \\
\text { Supérieure, Paris }\end{array}$ & 1 & 0.1 & 1 & 100 & & & 1 & & & & & \\
\hline Université de Paris & 1 & 0.1 & 1 & 100 & & & 1 & & & & & \\
\hline $\begin{array}{l}\text { Ecole des Hautes Etudes } \\
\text { en Sciences Sociales }\end{array}$ & 1 & 0.1 & 1 & 100 & & & 1 & & & & & \\
\hline $\begin{array}{l}\text { Université Pierre et Marie } \\
\text { Curie }\end{array}$ & 1 & 0.1 & 1 & 100 & & & 1 & & & & & \\
\hline Total & 5 & 0.5 & 5 & 100 & & & 5 & & & & & \\
\hline \multicolumn{13}{|l|}{ Germany } \\
\hline $\begin{array}{l}\text { Ludwig-Maximilians-Uni } \\
\text { versität }\end{array}$ & 1 & 0.1 & 1 & 100 & & & 1 & & & & & \\
\hline University of Heidelberg & 1 & 0.1 & 1 & 100 & & & 1 & & & & & \\
\hline
\end{tabular}




\section{Continued}

\begin{tabular}{|c|c|c|c|c|c|c|c|c|c|c|c|c|}
\hline University of Berlin & 1 & 0.1 & 1 & 100 & & & 1 & & & & & \\
\hline University of Frankfurt & 1 & 0.1 & 1 & 100 & & & 1 & & & & & \\
\hline University of Göttingen & 1 & 0.1 & 1 & 100 & & & 1 & & & & & \\
\hline University of Hamburg & 2 & 0.2 & 2 & 100 & & & 2 & & & & & \\
\hline University of Tübingen & 1 & 0.1 & 1 & 100 & & & & & 1 & & & \\
\hline Total & 8 & 0.83 & 8 & & & & 7 & & 1 & & & \\
\hline \multicolumn{13}{|l|}{ Switzerland } \\
\hline University of Bern & 1 & 0.1 & 1 & 100 & & & 1 & & & & & \\
\hline University of Geneva & 1 & 0.1 & 1 & 100 & & & 1 & & & & & \\
\hline Total & 18 & 1.9 & 16 & 88.9 & 2 & 11.1 & 15 & 2 & 1 & & & \\
\hline Europe Total & 78 & 8.1 & 63 & 80.8 & 15 & 19.2 & 56 & 13 & 4 & 1 & 3 & 1 \\
\hline$\%$ of all Fellows & & & 6.5 & & 1.6 & & 5.8 & 1.3 & 0.4 & 0.1 & 0.3 & 0.1 \\
\hline \multicolumn{13}{|l|}{ Caribbean } \\
\hline \multicolumn{13}{|l|}{ Caribbean } \\
\hline \multicolumn{13}{|l|}{ Dominican Republic } \\
\hline $\begin{array}{l}\text { Universidad Catolica } \\
\text { Madre y Maestra }\end{array}$ & 1 & 0.1 & 1 & 100 & & & 1 & & & & & \\
\hline \multicolumn{13}{|l|}{ Jamaica } \\
\hline $\begin{array}{l}\text { University of the West } \\
\text { Indies }\end{array}$ & 1 & 0.1 & 1 & 100 & & & & & 1 & & & \\
\hline Total & 2 & 0.2 & 2 & 100 & & & 1 & & 1 & & & \\
\hline \multicolumn{13}{|l|}{ Central America } \\
\hline \multicolumn{13}{|l|}{ Mexico } \\
\hline Instituto Allende & 1 & 0.1 & & & 1 & 100 & & & & 1 & & \\
\hline \multicolumn{13}{|l|}{ South America } \\
\hline \multicolumn{13}{|l|}{ Chile } \\
\hline $\begin{array}{l}\text { University of Chile in } \\
\text { Santiago }\end{array}$ & 1 & 0.1 & 1 & 100 & & & 1 & & & & & \\
\hline \multicolumn{13}{|l|}{ Argentina } \\
\hline $\begin{array}{l}\text { University of Buenos } \\
\text { Aires }\end{array}$ & 1 & 0.1 & & 0 & 1 & 100 & & 1 & & & & \\
\hline Total & 2 & 0.2 & 1 & 50 & 1 & 50 & 1 & & & & & \\
\hline $\begin{array}{l}\text { Latin America \& } \\
\text { Caribbean Total }\end{array}$ & 5 & 0.52 & 3 & 60 & 2 & 40 & 2 & 1 & 1 & 1 & & \\
\hline$\%$ of all Fellows & & & 0.3 & & 0.2 & & 0.2 & & 0.1 & 0.1 & & \\
\hline \multicolumn{13}{|l|}{ Oceania } \\
\hline \multicolumn{13}{|l|}{ Australia } \\
\hline $\begin{array}{c}\text { Australian National } \\
\text { University }\end{array}$ & 1 & 0.1 & 1 & 100 & & & 1 & & & & & \\
\hline
\end{tabular}




\section{Continued}

\begin{tabular}{|c|c|c|c|c|c|c|c|c|c|c|c|c|c|c|}
\hline University of Melbourne & 1 & 0.1 & 1 & 100 & & & 1 & & & & & & & \\
\hline University of New & & & & & & & & & & & & & & \\
\hline $\begin{array}{c}\text { England, New South } \\
\text { Wales }\end{array}$ & 1 & 0.1 & 1 & 100 & & & 1 & & & & & & & \\
\hline Total & 3 & 0.3 & 3 & 100 & & & 3 & & & & & & & \\
\hline$\%$ of all Fellows & & & 0.3 & & & & 0.3 & & & & & & & \\
\hline All Fellows & 965 & & 593 & 61.451 & 372 & 38.55 & 490 & 293 & 60 & 50 & 39 & 21 & 4 & 8 \\
\hline$\%$ of all Fellows & & & & & & & 50.8 & 30.4 & 6.2 & 5.2 & 4.0 & 2.2 & 0.4 & 0.8 \\
\hline
\end{tabular}

Note: $\mathrm{WM}=$ White men; $\mathrm{WW}=$ White women; $\mathrm{BM}=$ Black men; $\mathrm{BW}=$ Black women; $\mathrm{AM}=\mathrm{Asian}$ men; $\mathrm{AW}=\mathrm{Asian}$ women; NAM = Native American men; NAW = Native American women. Source: Compiled and computed based on data provided by the MacArthur Fellowship Program (June 2017 to February 2019) at: https://www.macfound.org/fellows/search/all.

\section{Appendix A. Regional Breakdown of the United States}

$$
(\mathrm{N}=51)
$$

Northeast ( $\mathbf{n}=9$ ): Connecticut, Maine, Massachusetts, New Hampshire, New Jersey, New York, Pennsylvania, Rhode Island, Vermont.

Midwest $(\mathbf{n}=\mathbf{1 2})$ : Illinois, Indiana, Iowa, Kansas, Michigan, Minnesota, Missouri, Nebraska, North, Dakota, Ohio, South Dakota, Wisconsin.

South $(\mathbf{n}=17)$ : Alabama, Arkansas, Delaware, District of Columbia, Florida, Georgia, Kentucky, Louisiana, Maryland, Mississippi, North Carolina, Oklahoma, South Carolina, Tennessee, Texas, Virginia, West Virginia.

West $(\mathbf{n}=13)$ : Alaska, Arizona, California, Colorado, Hawaii, Idaho, Montana, Nevada, New Mexico, Oregon, Utah, Washington, Wyoming.

Source: "Summary Social, Economic, and Housing Characteristics: 2000 Census of Population and Housing," (2003, June). Selected Appendixes: 2000. PHC-2-A. Washington, D.C.: U.S. Census Bureau.

Appendix B. Composition of Macro Geographical (Continental) Regions, Geographical Sub-Regions, and Selected Economic and Other Groupings Nations, Territories and Entities $(\mathrm{N}=246)$

\section{Africa $(\mathrm{N}=58)$}

Eastern Africa ( $\mathrm{n}=20)$ : Burundi, Comoros, Djibouti, Eritrea, Ethiopia, Kenya, Madagascar, Malawi, Mauritius, Mayotte, Mozambique, Reunion, Rwanda, Seychelles, Somalia, South Sudan, Tanzania, Uganda, Zambia, and Zimbabwe.

Middle Africa ( $(\mathbf{9}$ ): Angola, Cameroon, Central African Republic, Chad, Republic of Congo, Democratic Republic of Congo, Equatorial Guinea, Gabon and Sao Tome \& Principe.

Northern Africa $(\mathbf{n}=7)$ : Algeria, Egypt, Libya, Morocco, Sudan, Tunisia and Western Sahara.

Southern Africa ( $\mathrm{n}=5$ ): Botswana, Lesotho, Namibia, South Africa and Swaziland.

Western Africa ( $\mathbf{n}=17)$ : Benin, Burkina Faso, Cape Verde, Cote d'Ivoire, 
The Gambia, Ghana, Guinea, Guinea-Bissau, Liberia, Mali, Mauritania, Niger, Nigeria, Senegal, Sierra Leone, Togo and Saint Helena.

Americas $\mathrm{N}=57$

Latin America and the Caribbean $(n=52)$ :

Caribbean ( $=28)$ : Anguilla, Antigua and Barbuda, Aruba, Bahamas, Barbados, Bonaire, Sint Eustatius and Saba

British Virgin Islands, Cayman Islands, Cuba, Dominica, Dominican Republic, Grenada, Guadeloupe, Haiti, Jamaica, Martinique, Montserrat, Netherlands Antilles, Puerto Rico, Saint-Barthélemy, Saint Kitts and Nevis, Saint Lucia, Saint Martin (French part), Sint Maarten (Dutch part) Saint Vincent and the Grenadines, Trinidad and Tobago, Turks and Caicos Islands, United States Virgin Islands.

Central America $(\mathbf{n}=\mathbf{8})$ : Belize, Costa Rica, El Salvador, Guatemala, Honduras, Mexico, Nicaragua, Panama.

South America ( $n=16$ ): Argentina, Bolivia (Plurinational State of), Bouvet Island Brazil, Chile, Colombia, Ecuador, Falkland Islands (Malvinas), French Guiana, Guyana, Paraguay, Peru, South Georgia and the South Sandwich Islands Suriname, Uruguay, Venezuela (Bolivarian Republic of).

Northern America $(n=5)$ : Bermuda, Canada, Greenland, Saint Pierre and Miquelon, United States of America.

Asia $(\mathrm{N}=50)$

Central Asia $(\mathrm{n}=5)$ : Kazakhstan, Kyrgyzstan, Tajikistan, Turkmenistan, Uzbekistan.

Eastern Asia ( $=7$ ): China, Hong Kong Special Administrative Region of China, Macao Special Administrative Region of China, Democratic People's Republic of Korea, Japan, Mongolia, Republic of Korea.

South-eastern Asia ( $\mathbf{n}=11)$ : Brunei Darussalam, Cambodia, Indonesia, Lao People's Democratic Republic, Malaysia, Myanmar, Philippines, Singapore, Thailand, Timor-Leste, Viet Nam.

Southern Asia ( $\mathbf{n}=9)$ : Afghanistan, Bangladesh, Bhutan, India, Iran (Islamic Republic of), Maldives, Nepal, Pakistan, Sri Lanka.

Western Asia ( $\mathbf{n}=18$ ): Armenia, Azerbaijan, Bahrain, Cyprus, Georgia, Iraq, Israel, Jordan, Kuwait, Lebanon, Occupied Palestinian Territory (Gaza and the West Bank), Oman, Qatar, Saudi Arabia, Syrian Arab Republic, Turkey, United Arab Emirates, Yemen.

Europe $(\mathrm{N}=52)$

Eastern Europe ( $\mathbf{n}=10)$ : Belarus, Bulgaria, Czech Republic, Hungary, Poland, Republic of Moldova, Romania, Russian Federation, Slovakia, Ukraine.

Northern Europe ( $\mathrm{n}=17$ ): Åland Islands, Channel Islands (Guernsey, Jersey, Dark), Denmark, Estonia, Faeroe Islands, Finland, Iceland, Ireland, Isle of Man, Latvia, Lithuania, Norway, Svalbard and Jan Mayen Islands, Sweden, United Kingdom of Great Britain and Northern Ireland.

Southern Europe $(\mathrm{n}=16)$ : Albania, Andorra, Bosnia and Herzegovina, 
Croatia, Gibraltar, Greece, Holy See, Italy, Malta, Montenegro, Portugal, San Marino, Serbia, Slovenia, Spain, The former Yugoslav Republic of Macedonia.

Western Europe $(n=9)$ : Austria, Belgium, France, Germany, Liechtenstein, Luxembourg, Monaco, Netherlands, Switzerland.

Oceania $(\mathrm{N}=29)$ :

Australia and New Zealand ( $n=6)$ : Australia, Christmas Island, Cocos (Keeling) Islands, Heard Island and McDonald Islands, New Zealand, Norfolk Island.

Melanesia ( $\mathbf{n}=5)$ : Fiji, New Caledonia, Papua New Guinea, Solomon Islands, Vanuatu.

Micronesia ( $\mathrm{n}=\mathbf{8}$ ): Guam, Kiribati, Marshall Islands, Micronesia (Federated States of), Nauru, Northern Mariana Islands, Palau, United States Minor Outlying Islands

Polynesia ( $\mathbf{n}=10)$ : American Samoa, Cook Islands, French Polynesia, Niue, Pitcairn, Samoa, Tokelau, Tonga, Tuvalu, Wallis and Futuna Islands.

Source: "Composition of macro geographical (continental) regions, geographical sub-regions, and selected economic and other groupings" Retrieved on March 3, 2020 from: https://unstats.un.org/unsd/methodology/m49/ 